\title{
The Competitive Market
}

Value of Copyright in Music: A Digital Gordian Knot

MARCEL BOYER 
2017s-14

\title{
The Competitive Market Value of Copyright in Music: A Digital Gordian Knot
}

\author{
Marcel Boyer
}

\begin{tabular}{c}
\hline Série Scientifique \\
Scientific Series
\end{tabular}

\author{
Montréal \\ Octobre/October 2017
}

(C) 2017 Marcel Boyer. Tous droits réservés. All rights reserved. Reproduction partielle permise avec citation du document source, incluant la notice (․ Short sections may be quoted without explicit permission, if full credit, including (C) notice, is given to the source.
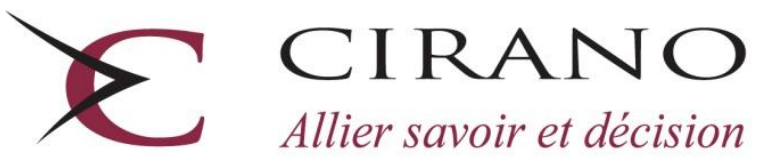

Allier savoir et décision

Centre interuniversitaire de recherche en analyse des organisations 


\section{CIRANO}

Le CIRANO est un organisme sans but lucratif constitué en vertu de la Loi des compagnies du Québec. Le financement de son infrastructure et de ses activités de recherche provient des cotisations de ses organisations-membres, d'une subvention d'infrastructure du gouvernement du Québec, de même que des subventions et mandats obtenus par ses équipes de recherche.

CIRANO is a private non-profit organization incorporated under the Quebec Companies Act. Its infrastructure and research activities are funded through fees paid by member organizations, an infrastructure grant from the government of Quebec, and grants and research mandates obtained by its research teams.

\section{Les partenaires du CIRANO}

\section{Partenaires corporatifs}

Autorité des marchés financiers

Banque de développement du Canada

Banque du Canada

Banque Laurentienne du Canada

Banque Nationale du Canada

Bell Canada

BMO Groupe financier

Caisse de dépôt et placement du Québec

Fédération des caisses Desjardins du Québec

Gaz Métro

Hydro-Québec

Innovation, Sciences et Développement économique

Intact

Investissements PSP

Ministère de l'Économie, de la Science et de l'Innovation

Ministère des Finances du Québec

Power Corporation du Canada

Rio Tinto

Ville de Montréal

\section{Partenaires universitaires}

École de technologie supérieure (ÉTS)

HEC Montréal

Institut national de la recherche scientifique (INRS)

McGill University

Polytechnique Montréal

Université Concordia

Université de Montréal

Université de Sherbrooke

Université du Québec

Université du Québec à Montréal

Université Laval

Le CIRANO collabore avec de nombreux centres et chaires de recherche universitaires dont on peut consulter la liste sur son site web.

Les cahiers de la série scientifique (CS) visent à rendre accessibles des résultats de recherche effectuée au CIRANO afin de susciter échanges et commentaires. Ces cahiers sont écrits dans le style des publications scientifiques. Les idées et les opinions émises sont sous l'unique responsabilité des auteurs et ne représentent pas nécessairement les positions du CIRANO ou de ses partenaires.

This paper presents research carried out at CIRANO and aims at encouraging discussion and comment. The observations and viewpoints expressed are the sole responsibility of the authors. They do not necessarily represent positions of CIRANO or its partners.

ISSN 2292-0838 (en ligne) 


\title{
The Competitive Market Value of Copyright in Music: A Digital Gordian Knot
}

\author{
Marcel Boyer ${ }^{*}$
}

\section{Résumé/Abstract}

Pricing copyrighted works or assets so that creators are fairly compensated, while users can benefit from the digital economy given the information good character of such works has always been a difficult task. Doing it in the digital era is even more challenging. Striking that balance and determining the proper royalty level and the efficient rate base require that the competitive market value of such copyright in musical works and sound recordings be ascertained. I review some of the challenges and pitfalls in adequately framing the issues, and review an approach to infer the competitive market value of music in commercial terrestrial/Hertzian radio, satellite radio and interactive music streaming services from choices of operators in those industries. The resulting royalty formulas and payments are embedded into and discussed through the economics of public policy towards culture (the elephant in the room). An Appendix presents the main characteristics of music copyright structures in different jurisdictions.

Mots clés/Key words: Music copyrights, Hertzian radio, Satellite radio, SiriusXM, Music streaming services, Pandora, Spotify, Cultural public policy.

\footnotetext{
* Marcel Boyer Ph.D., O.C., FRSC

Emeritus Professor of Economics, Université de Montréal

Associate Member, Toulouse School of Economics

Fellow, CIRANO
} 


\section{INTRODUCTION}

There is currently an important debate among both academics and professional practitioners on the proper definition, coverage and characterization of intellectual property rights of all kinds: patents, copyrights, trademarks, etc. In many jurisdictions, the legal foundations and enforcement of intellectual property rights are being questioned and reconsidered in the context of the digital era. New laws and extensive revisions of existent laws are discussed with powerful political and business groups on all sides of the debates.

At the center of those debates one finds arguments on the costs and benefits of protecting and enforcing intellectual property rights. The balance of costs and benefits is seen differently by different actors. Some see the costs of such policies, in terms of a lower dissemination of creations and innovations and therefore a loss of socio-economic value, in part in terms of further creations and innovations, as larger than benefits. Others see those benefits, in terms of adequate protection of intellectual property rights allowing proper compensation of creators and innovators thereby inducing them to increase their valuable and significant but risky investments in the production/expression of creations and innovations, as overshadowing costs.

Clearly, intellectual property rights should not be an impediment to further creations and innovations and therefore, should be properly defined and restricted in time and scope. As clearly, creations and innovations do not fall from heaven but are the results of significant efforts exerted and risks taken by creators and innovators. The balancing act here is to provide sufficient incentives for creators and innovators while at the same time foster the dissemination of creations and innovations. This is where market and market-like institutions for transactions on intellectual property rights, including fair use/dealing exceptions, compulsory licensing, as well as administrative boards and tribunals ${ }^{1}$ acting as social welfare maximizers or market surrogates, can play a major role.

The recorded music and book publishing industries are particularly important in the digital economy; for some observers, "music is leading the digital transition and fuels the Internet." ${ }^{2}$ First, recorded music and books are prone to digitization. Second, new technologies used to sell and distribute music and books on the Internet (webcasting and on-demand streaming, e-books) raise the possibility of valuable large-scale dissemination and customization at relatively low marginal costs. Those technologies open recorded music and book markets to increased intensities of competition due to the lower costs of entry of creators (authors, composers, performers, writers) on a world-wide and time-wide scale.

Those technological developments raise new risks of copyright erosion and inadequate or unfair

\footnotetext{
${ }^{1}$ Such as the US Copyright Royalty Board for sound recordings, the US Rate Courts for musical works, the Copyright Board of Canada for literary and musical works and sound recordings and other similar institutions elsewhere. See the Appendix for a brief survey of the different institutional frameworks of different jurisdictions.

${ }^{2}$ Cary Sherman, Chairman and CEO, Recording Industry Association of America (RIAA).
} 
compensation of creators. It has become increasingly difficult to affirm and enforce traditional intellectual property rights. ${ }^{3}$ And significant challenges pave the way to copyright reforms aimed at reaping the benefits of the digital technologies while protecting creators.

Although the challenges and pitfalls are similar in the literary works and musical works fields, the rest of this paper will mainly deal with music for reasons of simplicity and clarity. But most of it can be read mutatis mutandis with in mind literary works or patents, scientific contributions, as well as innovations.

Copyright comes in many forms: the exclusive right of authors, composers and music publishers to the communication/transmission as well as to the reproduction of their works, the fair compensation right of performers and makers of sound recordings. The communication / transmission and the reproduction of works and sound recordings come also in different forms, depending on the industry considered and the technology used.

\section{The Market Dynamics}

In a recent paper, ${ }^{4}$ I presented as follows some of the market dynamics going on in the field of copyright. As the debate on the re-examination of copyright legal foundations and enforcement, coverage, exceptions, and compensation takes place, the market or markets of music delivery are changing rapidly.

According to Nielsen Music360 Report (2015), ${ }^{5}$ Americans streamed 135 billion tracks in the first half of 2015, an increase of more than $90 \%$ from the first half of 2014 . However, only $9 \%$ of them expect or are likely to subscribe or pay for streaming music in the next 6 months. One may wonder why the vast majority of people are thus refusing to put their hand in their pocket to have access to (almost) all the music in the world. ${ }^{6}$ It is interesting to note that although online streaming is increasing rapidly, about $60 \%$ of respondents say they rely on radio, Hertzian or satellite, to find out about new music.

In a Report released in March 2017, the Phoenix Center claims that: " In 1999, the year the Digital Millennium Copyright Act ("DMCA") was enacted, revenues for the recording industry in the

\footnotetext{
${ }^{3}$ A striking case at hand is private copying exception and provisions where the early promises of fair compensation for the expropriation of reproduction rights disappeared in some jurisdictions (Canada for instance) but maintained in others (France and Germany for instance). See my recent paper "The Economics of Private Copying” (July 2017b).

${ }^{4}$ Marcel Boyer (2017a), “The Three-Legged Stool of Music Value: Hertzian Radio, SiriusXM, Spotify,” August 31, a slightly version of https://www.tse-fr.eu/sites/default/files/TSE/documents/ChaireJJL/PolicyPapers/pp the threelegged_stool_of_music_value hertzian_radio_siriusxm_spotify marcel_boyer_july_2017.pdf

${ }^{5}$ http://www.nielsen.com/us/en/insights/reports/2015/music-360-2015-highlights.html

${ }^{6}$ Spotify, the leading interactive streaming service, has over 30 million pieces of music in its repertoire.

${ }^{7}$ T. Randolph Beard, George S. Ford, and Michael Stern (2017), Safe Harbors and the Evolution of Music Retailing, Phoenix Center Policy Bulletin No. 41, March. http://www.phoenix-center.org/PolicyBulletin/PCPB41Final.pdf
} 
United States reached nearly $\$ 21$ billion (in current dollars), growing nearly 5\% annually over the preceding decade. The future looked bright. Fifteen years later, due in large part to digital piracy made possible by technology and high-speed Internet connections, sales were only $\$ 7$ billion, a decline of $65 \%$ in real terms."

According to RIAA "Although our 2016 revenue report catalogues substantial overall improvement for the industry, revenues [7.7 billion US \$] are still only about half what they were in 1999, and revenues from more traditional unit-based sales (physical products and digital downloads) continued to decline significantly ... [The] streaming music platforms generated the majority [51\%, with Digital Downloads and Ringtones 24.1\% and Physical sales 21.8\%] of the U.S. music industry's revenues. The streaming category includes revenues from subscription services (such as paid versions of Spotify, TIDAL, and Apple Music), streaming radio services including those revenues distributed by SoundExchange (like Pandora, SiriusXM, and other Internet radio), and ad-supported on-demand streaming services (such as YouTube, Vevo, and adsupported Spotify) ... In 2016, revenues from sales of digital tracks and albums declined faster than in any previous year. Overall digital download revenues were $\$ 1.8$ billion, down $22 \%$ versus 2015. Individual track sales revenue was down 24\%, and digital album revenue was down $20 \%$ compared with the previous year. Revenues from sales of digital albums were $49 \%$ of the download total, their highest share ever ... The industry showed another increase, albeit from levels that remain well below their peak in the late 1990's. The growth of streaming music and prevalence of digital platforms show that music consumption is higher than ever - which is great for fans. But challenges remain significant as physical shipments and digital downloads, two of the industry's three major revenue sources, continued to decline in 2016. A similar evolution is observed in other countries."

However, U.S. radio listening hours in 2016 is still accounted for mostly by traditional radio, Hertzian (79\%) and Satellite (8\%), while webcaster Pandora is coming at $10 \%$. Regarding U.S. music streaming hours, Pandora leads with $55 \%$ followed by Spotify at $32 \% .{ }^{9}$ On a worldwide scale, Pandora and Spotify appear neck to neck. As a whole, music represents $79 \%$ of audio listening time. ${ }^{10}$ And $61 \%$ of Americans say that they discover music through radio (AM/FM and Satellite) compared to $27 \%$ for online audio or video streaming websites/apps. ${ }^{11}$

Interlocking financial arrangements are also developing. Major music labels appear to be holding minority stockholder positions in Spotify, namely Sony BMG (5.8\%), Universal Music (4.8\%),

\footnotetext{
${ }^{8}$ Joshua P. Friedlander, News and Notes on 2016 RIAA Shipment and Revenue Statistics, RIAA.

${ }^{9}$ Pandora Analyst Day, October 252016.

${ }^{10}$ Edison Research, Share of Music - A Share of Ear Report, Q2 2016. Besides music at 79\%, we find mews at 9\%, talk/personalities at $9 \%$, and sports at $3 \%$.

11 Nielsen Music 360 Report, 2015.
} 
Warner Music (3.8\%), and Merlin. ${ }^{12}$ Moreover, it was announced on June 92017 that SiriusXM invested US\$ 480 million for a 19\% stake in Pandora and obtained three seats on its board of directors. ${ }^{13}$ Rightsholders organizations are also active on that front. It was announced recently that U.S. based SoundExchange acquired the Canadian Musical Reproduction Rights Agency (CMRRA). The acquisition of CMRRA will provide SoundExchange, a sound recording collective present in the digital world, with an "opportunity to enter the music publishing administration market. The transaction comes at a time of increasing consolidation in the marketplace, so this is another example of the changing market." Those are the most recent among other cross ownership deals that existed in the recent past and exist today.

Such financial deals in a sense blur the lines between different business models in the music delivery industry and it is not clear how they will impact the intensity of competition among the different (digital) technologies and models as well as the copyright royalties. But one thing is clear: unless rightsholders remain on their toes and avoid the risky position of residual claimants in the development of the digital age, they will end up on the losing side of history.

\section{The Principles}

Three principles are at the forefront of the copyright pricing challenge:

- First, the competitive level playing field principle, which ensures that all uses of musical works and sound recordings, whether in hard or digital form, compete for customers on equal terms given the various business models characterizing the different users: same pricing for similar uses, different but compatible pricing for different uses;

- Second, the competitive market value principle, which ensures that the compensation of rightsholders achieve fairness for both users and rightsholders as well as efficiency and effectiveness;

- Third, the information good pricing principle, which ensures that users can have notional access if not consume all available musical works given that those musical works are permanent, that is, not expended in consumption.

\section{The Challenges and Pitfalls}

The challenges and pitfalls are numerous:

1) Moving away from simple heuristics and traditional analysis towards sounder, more advanced economic analysis and renewed institutional frameworks is a demanding endeavor, which

\footnotetext{
${ }^{12}$ As reported by Swedish Wire, July 42017.

${ }^{13}$ Janko Roettgers, "Why the SiriusXM Investment in Pandora is a Win-Win Situation”, Variety, June 92017.
} 
could be miscarried if not properly understood;

2) Musical works are costly information goods or assets: the creation or production of the first copy may require significant resources of the intellect (human capital) and may be risky, but once created the work can be consumed simultaneously or subsequently by multiple users without depleting the quality or quantity of the good or asset available to any of them;

3) The level of royalties being paid by users to rightsholders is one concern, but the distribution of the pie among creators of different types/groups (authors, composers, music publishers, performing artists, producers of sound recordings, and music labels) is also a major but different concern. ${ }^{14}$

4) Digitization is a drastic innovation that reduces significantly the dissemination costs of music and books, thereby challenging the delicate balance between the creators' right to a fair compensation and the users' right to the benefits of digital technologies, which, combined with the "information" good character of music, makes the pricing issue more complex, more challenging and exacerbating;

5) Copyright made works excludable information goods, thereby favoring the emergence of markets and market-like or market-surrogate institutions, but the excludability level that copyright was supposed to ensure may have become too severe for the digital world, hence socially less efficient and less effective than before; the advent and growth of digital technologies have favored an increase in the value of music, but at the same time put more emphasis on making it more available than before, in a sense reducing the desirable level of excludability; hence the movement for "freer or free music and books";

6) The digital revolution comes at a time when the "value" of copyrighted musical works appears to be both significantly underestimated and continuously eroded by new copyright exceptions and limitations, as well as easier illegal copying;

7) The current framework of sequentially determining royalty payments and rates, each case being heard or negotiated on a standalone basis thereby making it difficult for the royalty

\footnotetext{
${ }^{14}$ Suzanne Combo of GAM (Guilde des Artistes de la Musique -France- defending the interests of authors and composers) claims that « Les grands gagnants du streaming restent les majors. Les contrats des artistes, tous confidentiels et qui varient selon leur notoriété, ne sont pas adaptés car ils sont calqués sur l'ancien modèle de la vente des disques ... Le contrat prévoit pour l'artiste de $10 \%$ à $12 \%$ des sommes nettes encaissées par le producteur ... L'assiette reste opaque et douteuse puisque le producteur n'a plus de frais de stockage ni de fabrication, comme pour un CD. De plus, l'artiste finance une partie de la promotion. Si bien qu'à la fin il ne touche souvent pas plus de $5 \%$... les deals entre les majors et les plates-formes - les premières étant d'ailleurs actionnaires minoritaires des secondes -, et sur les abattements appliqués pour diminuer la rémunération de l'artiste. Dans leur ensemble, les artistes ignorent la teneur des échanges entre labels, producteurs et sociétés de streaming » (Le Monde, Éco\&Entreprise, 1 mars 2017).
} 
boards as well as negotiated contracts to implement significant adjustments; if all rates were to be determined at the same time, a level playing field of competition could more easily (!) be maintained with the different rates being based on proper competitive market values; making changes in a sequential fashion may prevent the unavoidable challenges of the status quo;

8) There is always a real danger of inadvertently tilting the level playing field of competition between different delivery technologies of musical works, namely traditional, analogue, digital, and Internet technologies, which are all competing for listeners' ears;

9) There is also a real danger to lose sight of the forest for the tress, as the big picture itself keeps evolving; as the US Copyright Office (2015) puts it: "The Copyright Office has previously highlighted the outmoded rules for the licensing of musical works and sound recordings as an area in significant need of reform. Moreover, the Office has underscored the need for a comprehensive approach to copyright review and revision generally. This is especially true in the case of music licensing - the problems in the music marketplace need to be evaluated as a whole, rather than as isolated or individual concerns of particular stakeholders."

The competitive pricing of copyrights in such a context aims to achieve both balance and neutrality between rightsholders' rights and users' rights, both business users' rights and consumers' rights, through the proper compensation of creators for the valuable assets they create, the proper compensation of business users for the costs and risks they incur, and the proper if not maximal dissemination of musical creations. Achieving such competitive pricing requires to move away from traditional heuristics toward sounder analytics.

Indeed, the current procedures for determining royalty payments and rates are based mainly if not totally on path-dependent heuristics and rules of thumb whose foundations in theoretical and applied economics are relatively weak and clearly inadequate to tackle the current and upcoming copyright agenda.

\section{The Fundamental Issues and Questions}

The fundamental issues or questions before us are the following:

a) What is or are the competitive market value/values of copyright given the "information good" aspect of copyrighted works (music and books), as the advent of digitization makes the emergence of properly functioning competitive markets difficult, even impossible?

b) How to balance the creators' right to a fair compensation and the users' right to the benefits of digital technologies, at a time when the conflict between fairness and efficiency has become more acute than ever before?

The competitive market value principle, which is the very foundation of the proper or fair 
compensation of creators, relies on the consumers' valuation of music and willingness to pay for it. But the ways payments are to be made may not be the traditional ways (tariffs or per play rates). A consumers' advocate economist would say: Although we value music a lot and want to consume more of it and although we want creators and providers of such music to be properly compensated (competitive market compensation), the pricing of such music should take into account the fact that music is an information good or asset and the fact that adding consumers or enhancing dissemination of works cost almost nothing. This calls for a significant reassessment of both the way copyright protection has historically been understood and enforced and the channels through which creators' proper or fair compensation can be achieved. This is at best a difficult multifaceted endeavor, whose end point solution likely lies outside the box.

\section{Section 1. Copyright and the New Digital Economy}

With these trends as background, the digital era can be defined as encompassing drastic innovations in the production and distribution or dissemination technologies as well as in business organization and governance associated with the digitization of goods and services and the digitalization of firms and businesses. ${ }^{15}$ Their impacts on the competitive landscape of markets, in particular markets for intellectual property products such as copyrighted musical works, is of major importance. All current and past musical works of the world are literally and increasingly becoming available to all at a low if not zero marginal dissemination cost.

The significant reduction of dissemination costs of music poses important challenges for the delicate balance between creators' right to a fair compensation or a fair share of the value of their works and the users' right to the benefits of digital technologies.

The situation is made even more challenging as musical works are "information goods": once produced, each unit can be "consumed" by all, as one person's use (listening or reading) of a work does not prevent its simultaneous or subsequent use by others. Moreover, musical works are assets that survive indefinitely with no physical depreciation. Hence, they are better referred to as "information assets".

Although related, the "information asset" character of musical works and sound recordings and the digital character of music are two different challenging factors in the current copyright landscape. The first one relates to the permanence of the product or asset as one's consumption of a unit does not destroy the unit, which remains fully and unabatedly available for everyone else now and in the future, while the second one relates to the distribution or dissemination costs of that product or asset.

${ }^{15}$ The Oxford English Dictionary (OED) traces the first uses of the terms 'digitization' and 'digitalization' in conjunction with computers to the mid-1950s. In the OED, digitization refers to "the action or process of digitizing; the conversion of analogue data (esp. in later use images, video, and text) into digital form." Digitalization, by contrast, refers to "the adoption or increase in use of digital or computer technology by an organization, industry, country, etc." 
According to Nielsen Music360 Report (2015), ${ }^{16}$ Americans streamed 135 billion tracks in the first half of 2015, an increase of more than $90 \%$ from the first half of 2014 . However, only $9 \%$ of them expect or are likely to subscribe or pay for streaming music in the next 6 months. One may wonder why the vast majority of people are thus refusing to put their hand in their pocket to have access to (almost) all the music in the world. ${ }^{17}$ It is interesting to note that although online streaming is increasing rapidly, about $60 \%$ of respondents say they rely on radio, Hertzian or satellite, to find out about new music.

Therefore, music streaming is the fast growing segment of the music industry, but people seem reluctant to paying for the service because they know in a sense that the marginal dissemination costs of music are close to zero. Interestingly, the same trends goes on for books and e-books. The Malka Report (see below) lists 21 planned "compulsory" exceptions to EU copyright law. If enacted, they would seriously undermine the capacity of the book publishing industry to pay fair compensation to authors and creators. One of those exceptions for instance would allow libraries to lend e-books without limit of time or number, a serious threat of cannibalization of book and eBook sales and possibly of royalties.

Before the advent of digitization, music and books were information assets whose distribution costs were significant, while those latter costs are now reduced to almost zero. Marginal distribution or dissemination costs were possibly sufficiently high to allow profits over variable costs to cover the cost of creation itself through royalties. It may not be the case anymore.

The digital revolution comes at a time when the "value" of copyrighted works appears or is claimed to be both significantly underestimated and continuously eroded by new copyright exceptions, while being challenged by users' groups among others claiming that a reduction in copyright scope and duration would favor an increase in social and economic welfare as well as a more intensive and extensive development of innovations and creations.

Striking the right balance between creators' and users' rights in such a context is a difficult and multifaceted endeavor for all those different reasons. In a nutshell: musical works are costly information assets; digital technologies reduce the marginal cost of dissemination or distribution of works to almost zero; copyright made works excludable information assets, thereby favoring the emergence of markets and market-surrogate institutions, but this excludability level may have become too severe for the digital world, hence possibly less efficient at its current level and less effective than before.

The digital era raises significant challenges for the valuation and pricing of musical works. Hence the importance for economic theorists and empirical economists to take a serious look at the paradigm-changing potential that comes from large scale digitization, digitalization, dissemination

\footnotetext{
16 http://www.nielsen.com/us/en/insights/reports/2015/music-360-2015-highlights.html

${ }^{17}$ Spotify, the leading interactive streaming service, has over 30 million pieces of music in its repertoire.
} 
and customization both to better understand those phenomena and to suggest adequate efficiencyprone policies. $^{18}$

\section{The economics program}

Indeed, two important objects of economics as a social science are first the analysis of static and dynamic mechanisms that can best contribute to meeting the virtually unlimited needs of human beings with the limited resources available to them, and second the design and characterization of those institutions that can implement or concretize those mechanisms. The appropriate welfaregenerating production and distribution mechanisms and institutions will depend on the nature and characteristics of the goods and services that citizens and consumers demand or need.

The world of copyright is in deep turmoil. And law and economics questions are raised. Why do we observe an increasing breath, intensity and scope of fair use/dealing exceptions? If fairness in compensation must be based on competitive market compensation, then what is the "competitive market compensation" level in the context of information assets with quasi zero dissemination or distribution costs (digital technologies)? Should fair use/dealing provisions be compensated? If yes, by whom? What about other exceptions? Why not make copyrighted works royalty-free? And if so, how can creators' compensation be assured?

\section{Recent debates and projects of reforms}

Four recent reports among others spell out those concerns: ${ }^{19}$ Caroline de Cock, The Copyright Manifesto (January 2015); Julia Reda (Committee on Legal Affairs of the European Parliament), Draft Report on the implementation of Directive 2001/29/EC of the European Parliament and of the Council of 22 May 2001 on the harmonisation of certain aspects of copyright and related rights in the information society (January 2015); Richard Malka, 2015: The End of Copyright - Taking for free is Stealing (2015); and The US Copyright Office, Copyright and the Music Marketplace: A Report of the Register of Copyrights (February 2015).

In The Copyright Manifesto (January 2015), Caroline de Cock, coordinator of the advocacy group Copyright 4 Creativity, claims that the current fragmented copyright system in Europe is detrimental to the development of creativity in the digital age. She proposes an extension of fair

\footnotetext{
${ }^{18}$ The Honorable David R. Strickler of the US Copyright Royalty Board, the institution responsible for the determination of royalty rates and terms for statutory licenses of copyrights on sound recordings, emphasizes the judicial need for continued and comprehensive research in copyright economics in "Royalty Rate Setting for Sound Recordings by the United States Copyright Royalty Board: The Judicial Need for Independent Scholarly Economic Analysis," Review Of Economic Research on Copyright Issues 12(1/2), 1-15.

${ }^{19} \mathrm{http}$ ://copyright4creativity.eu/wp-content/uploads/2015/01/C4C-Copyright-Manifesto-20150119.pdf http://www.europarl.europa.eu/sides/getDoc.do?pubRef=-//EP//NONSGML+REPORT+A8-2015$0209+0+\mathrm{DOC}+\mathrm{PDF}+\mathrm{V} 0 / / \mathrm{EN}$

http://www.sne.fr/wp-content/uploads/2015/09/R.Malka_TakingForFreeIsStealing.pdf https://www.copyright.gov/policy/musiclicensingstudy/copyright-and-the-music-marketplace.pdf
} 
use exceptions and their harmonization across Europe. She writes: "Under current EU law, copyright harmonization is limited to the exclusive right of the rightholder of an original work, but fails to address the other part of the system, namely the exceptions and limitations"; "libraries, archives and cultural heritage institutions are limited in their public mission to provide access to and preserve knowledge and culture, as copyright rules or licensing conditions prohibit them from embracing technological evolution"; and "In Europe, innovators often have to rely on exceptions and limitations to give them room to spread their wings."

She argues in favor of a so-called modernization of copyright laws and regulations, including the extended fair use/dealing exceptions to be made mandatory across the European Union and the reduction of copyright duration. She calls for more "thorough analysis of the economics underlying the creation and dissemination of culture."

In Draft Report on the implementation of Directive 2001/29/EC of the European Parliament and of the Council of 22 May 2001 on the harmonisation of certain aspects of copyright and related rights in the information society (January 2015), Julia Reda, rapporteur of the Committee on Legal Affairs of the European Parliament, echoes similar concerns namely that ${ }^{20}$ "The provisions of 2001 's copyright directive have not been able to hold step with the increase of cross-border cultural exchange facilitated by the Internet. The current copyright regime hinders the exchange of knowledge and culture across borders. To meet current challenges, the legislation needs to be updated to current practices and harmonised further." ${ }^{21}$ The report promises that authors' rights will be strengthen but does not include specific measures to that effect. It does argue for harmonization across Europe with a reduction of copyright duration and easier access to copyrighted works through digital technologies, making expanded exceptions mandatory across Europe, and favoring transformative creations, that is, the creation of new works by transforming existing ones (remixes and mashups). Regarding those, she writes "Copyright legislation should not stand in the way of this unprecedented wave of emerging creative expression and should recognise new creators as valid cultural actors and stakeholders" (emphasis added) .The report proposes an important specific expansion of fair use provisions for research and education and an additional exception for libraries to make lending of books in digital forms (e-books) easier and more pervasive.

Those two reports were sharply criticized by copyright lawyer Richard Malka ${ }^{22}$ in the 2015 pamphlet The End of Copyright? Taking for free is Stealing. He summarized the attempt to renew European copyright laws as follows: "[T]he European Commission, confronted with an individual in perfect health, has pronounced him ill in order to cure him with lethal medication." He claims

\footnotetext{
20 This refers to Directive 2001/29/EC of the European Parliament and of the Council of 22 May 2001 on the harmonisation of certain aspects of copyright and related rights in the information society [the so-called InfoSoc Directive].

${ }^{21}$ See Julia Reda, Reda Report Draft - Explained at https://juliareda.eu/copyright-evaluation-report-explained/

${ }^{22}$ And a long time counsel of Charlie Hebdo.
} 
that the European copyright system is complex but functional, that it is far from broken as it is the result of numerous "compromises that have been reached by mutual consent," and that there is no reason to introduce a whole set of new exceptions that would benefit large multinational corporations at the expense of creators and rightsholders.

Malka claims that those newly defined exceptions "would be so far-reaching and so hard to monitor that the principle of sales-related compensation become as fictional as teleportation." Among the newly defined exceptions that Malka considers dangerous for rightsholders, one finds the redesigned right for libraries to lend e-books and give access to their collections (risk of cannibalization from less controlled or uncontrolled eBook lending); the text and data mining exception allowing users "to copy protected content found in digital data bases free of charge, in order to undertake research on that content and create, out of this extraction, original content"; the educational exception which "would authorize the free copying of portions of content for educational purposes, which would de facto lead to the exponential growth of unrecorded copies that would unfairly compete with publishers' offerings" and introduce a risk of devastating the textbook market; the fair use exception; and the exception for transformative use. ${ }^{23}$

In Copyright and the Music Marketplace: A Report of the Register of Copyrights (February 2015), an official report of the US Copyright Office USCO, Maria A. Pallante, Register of Copyrights and Director of USCO, develops "a series of guiding principles and preliminary recommendations for change ... meant to be contemplated together, rather than individually." Affirming that the time is ripe to question the existing paradigm for the licensing of musical works and sound recordings, the report addresses concerns of songwriters and recording artists "that they cannot make a living under the existing structure" while "music publishers and performance rights organizations are frustrated that so much of their licensing activity is subject to government control" and therefore constrained in the marketplace and making it difficult to innovate. As in Europe there is a general if mixed consensus in the USA regarding the need for reform. But the consensus brakes down when specific measures and changes are considered, especially if they are considered individually.

Among the most important recommendations of the USCO, one finds the following five. First, the need to extend the public performance right in sound recordings to presently exempted terrestrial radio broadcasts; Second, the adoption of a unique market-based rate setting standard, whether denominated "willing buyer/willing seller" or "fair market value" hence mimicking rates that would be negotiated in an unconstrained market, in order to stop the subsidization by music creators of users who seek to profit from their works; Third, the licensing of mechanical rights on a blanket basis bundled with performance rights, possibly under the same collectives, with an opt-out option for digital rights; Fourth, the creation of a general music rights organization GMRO to maintain a publicly accessible database of musical works and sound recordings appropriately matched to

\footnotetext{
${ }^{23}$ Richard Malka's representation of the Reda Report may at times be somewhat exaggerated in its description of some of the proposed exceptions and in its evaluation of the risks that rightsholders are facing. Nonetheless, his analysis is clearly of high relevance.
} 
simplify and facilitate more efficient licensing; Fifth, the regrouping of all government rate setting under the Copyright Royalty Board, hence the abolishment of rate courts currently in charge of setting rates for musical works.

The advent and growth of digital technologies have favored an increase in the value of musical works insofar as consumption has increased, but at the same time have put more emphasis on social demands to make them more available than before, in other words have put more emphasis on reducing the excludability that the granting of copyright was and is supposed to ensure.

Such a proposed policy of making music and books more widely available, that is, freer or at lower prices overall, begs the question: who should bear the cost of such a policy? The creators as providers of musical works and sound recordings? Alone or along with some other groups? Indeed, the cost of a public policy of enhanced dissemination of copyrighted works through lower royalties and expanded exceptions and limitations of copyright can be expressed in terms of the compensation of creators.

Whatever the public policy pursued, it would be wrong to simply expropriate the intellectual property of rightsholders without properly compensating them. And properly compensating rightsholders requires ab ovo a sound understanding of the competitive market value of copyright in musical works.

The de Cock Manifesto and the Reda Report briefly discussed above may be relatively extreme demands for reforms of copyright laws and regulations with their calls for reducing the duration of copyright and for expanding the exceptions and limitations (including fair use/dealing provisions) to the expression of copyrights, but they are part of a larger "freer or free music and books" movement.

\section{Fair use/dealing in copyrighted works}

Fair use/dealing in copyrighted works is a central exception in the current debate. It warrants some discussion as one must properly understand and apply the present and proposed fair use/dealing objectives and provisions as well as the associated regulatory frameworks. A rigorous economic analysis is essential for that matter, as fair use/dealing is too important to be left to legal squabbles.

Fair dealing in the UK/Canada is an expression equivalent to the US fair use but their nature and scope differ in some ways. ${ }^{24}$ It might be interesting to mention at the outset that the US Copyright Office leaflet on Fair Use (2009) states (passim): the right to reproduce or to authorize others to reproduce the work is subject to certain limitations, one of the more important ones being the doctrine of fair use. This doctrine has developed through a substantial number of court decisions over the years and has been codified in Section 107 of the law with a list of purposes for which the

\footnotetext{
${ }^{24}$ For a comparative analysis of fair use in the US and fair dealing in the UK and Canada post-CCH, see G. D'Agostino (2008), "Healing Fair Dealing? A Comparative Copyright Analysis of Canadian Fair Dealing to UK Fair Dealing and US Fair Use," McGill Law Journal 53(2), 309-364.
} 
reproduction of a particular work may be considered fair: criticism, comment, news reporting, teaching, scholarship, and research. The distinction between fair use and infringement may be unclear and not easily defined as there is no specific number of words, lines, or notes that may safely be taken without permission and simply acknowledging the source of the copyrighted material does not substitute for obtaining permission. The Office goes on by stating that copyright protects the particular way authors have expressed themselves but it does not extend to any ideas, systems, or factual information conveyed in a work. It states also that the safest course is always to get permission from the copyright owner before using copyrighted material. When it is impracticable to obtain permission, use of copyrighted material should be avoided unless the doctrine of fair use would clearly apply to the situation. If there is any doubt, it is advisable to consult an attorney.

For the record, The Canadian Copyright Act contains several exceptions to sole rights of copyright holders, including the provisions on fair dealing: fair dealing for the purpose of research, private study, education, parody or satire does not infringe copyright (s. 29); fair dealing for the purposes of criticism or review does not infringe copyright (s 29.1), but some specific factors pertaining to the work must be mentioned such as the source and the name of the author, performer, maker, or broadcaster; fair dealing for the purpose of news reporting does not infringe copyright if the above factors are mentioned (s 29.2). For fair dealing, it is not necessary to obtain the consent or authorization of the copyright holder, even if the behaviour or action of the user would normally constitute a copyright violation.

The analysis of fair use/dealing falls at the intersection of law and economics, more specifically within a law and economic framework. In that spirit, I proposed in Boyer (2012) ${ }^{25}$ an economic analysis of the landmark decision of the Supreme Court of Canada (SCC) in CCH Canadian Ltd. v. Law Society of Upper Canada $(\mathrm{CCH})$ and came to the following conclusions.

First, there are purely economic reasons for the fair dealing exception to the exclusive rights of creators over their works.

\footnotetext{
${ }^{25}$ Marcel Boyer (2012), "The Economics of Fair Use/Dealing: Copyright Protection in a Fair and Efficient Way", Review of Economic Research on Copyright Issues 9(1), 2012, 3-46

http://papers.ssrn.com/sol3/papers.cfm?abstract $\mathrm{id}=2101080 \#$ \#. The contribution of the article was voluntarily limited in scope and should not be amalgamated with comprehensive overviews of the fair dealing / fair use compact. There is an extensive and conflicting literature (mainly legal in scope) on the nature, role and desirability or necessity of fair dealing and fair use exceptions in copyright laws. This literature is comprised of academic articles as well as analyses of (best) practices related to these exceptions, through case law and jurisprudence. Besides the fact that simply reviewing the most important contributions would require a whole paper, it would make us lose sight of the chosen limited and specifically economic scope. For such more comprehensive overviews, see in particular W.J. Gordon (1982), "Fair Use as Market Failure: A Structural and Economic Analysis of the Betamax Case and Its Predecessors," Columbia Law Review 82, 1600; W.M. Landes and R.A. Posner (1989), "An Economic Analysis of Copyright Law," Journal of Legal Studies 18, 325-354; L.P. Loren (1997), "Redefining the Market Failure Approach to Fair Use in an Era of Copyright Permission Systems," Journal of Intellectual Property Law 5, 1-58; M. Africa (2000), “The Misuse of Licensing Evidence in Fair Use Analysis: New Technologies, New Markets, and the Courts," California Law Review 88, 11451184; G. D’Agostino (2008), "Healing Fair Dealing? A Comparative Copyright Analysis of Canadian Fair Dealing to UK Fair Dealing and US Fair Use," McGill Law Journal 53(2), 309-364; and the many references therein.
} 
Second, it is in the interest of a socially efficient static and dynamic allocation of resources to the production and dissemination of works, in a manner consistent with the SCC decision in $\mathrm{CCH}$, that this fair dealing exception be an integral part of the rights of users and ought not to be unduly thwarted. This is particularly the case when research and private study are the purposes of the use. In so doing, we must avoid unintended harm to copyright and foster the emergence of efficient means of exchange (market-based institutions) between users and creators. It is within this analytical framework that we must consider not only alternatives to the use of works but also alternatives to the exercise of the fair dealing exception itself.

Third, there are economic reasons for the absence of efficient exchange mechanisms (efficient markets) in copyright, particularly with respect to the right to reproduce works. This absence of efficient market mechanisms may have socially undesirable consequences on the production and distribution of original works, hence the importance of properly understanding the underlying reasons for such an absence in order to be able to devote resources to solve the problems that may arise as a result.

Fourth, the identification and measurement of the effects of fair dealing on the work, the markets for the works, and hence their value are certainly factors that are relevant in establishing a reasonable framework for this copyright exception. The way in which those effects are measured must, if the expected results are to be achieved, be based on a broadened definition of the concept of a "market" and hence a broadened definition of the concept of "value." A market, from the standpoint of economic theory and analysis, includes not only the units transacted between sellers and buyers, but also potential buyers (those who would buy or buy more at a lower price) and potential sellers (those who would sell or sell more at a higher price), as well as future buyers and sellers. It includes also information providers who assess, analyze, or confirm the quality of goods and services, market analysts, journalists who make sure that accurate news is available, and suppliers of ancillary services within a market or related to a market. Finally, it includes the institutions that organize and facilitate transactions and process the associated financial transactions ensuring the necessary market liquidity, etc.

Fifth, preference should be given to policies that aim to create efficient, simple and low-cost market or market-like mechanisms and institutions that foster the production, distribution, and reproduction of quality original works, with due regard to the rights of authors and creators as well as users. In the later part of this article, I describe a market-like based mechanism which would not only favor a maximal dissemination of works but also avoid unnecessary recourse to the fair dealing exception.

It is appropriate here to mention that the economic interpretation (or at least my own interpretation as an economist) of the fair dealing exception is that it is simply a mean to achieve the broad objective of providing optimal incentives for creators and maximal dissemination of works under severe informational constraints and therefore restricted efficiency conditions rather than a fundamental right associated with free speech. An anonymous referee wrote: “... a blanket license scheme won't work for the cases that matter most to Americans when we think of fair use. The 
author has a narrow view of what fair use is about. At a minimum he/she should acknowledge that it's his/her view, not the dominant of judicial view."

Hence, a proper interpretation of what the SCC may or must have meant in CCH rests on the objectives pursued by the exception. Two elements of the decision are particularly important: the role of alternatives to the dealing in the work and the effect of the dealing on the work.

The SCC stated in particular that existence of "alternatives" such as "non-copyrighted equivalent" works or "alternatives to the custom photocopy services" needs to be considered when deciding whether to allow a defense of fair dealing. When such alternatives exist, the dealing is likely unfair. However, the existence of a license is not considered by the SCC as a proper alternative to judge if the dealing is fair or not. I argued that "alternatives" shouldn't be seen only as "alternatives to dealing in the work." In addition, the inquiry should also consider the examination of alternatives to fair dealing in the work. The difference is important and crucial. For example, the existence of an efficient and inexpensive mechanism that could allow users to acquire copyrights without relying on the fair dealing exception should be considered as an alternative not to the use of the work itself but to the reliance on the fair dealing exception.

Regarding the effect of the dealing on the market for the works, I argued first that the preferred copyright policy should be to create properly designed efficient market-like mechanisms and institutions to favor copyright transactions, such as blanket licenses priced through copyright boards acting as surrogates for competitive markets, and second that the first step in allowing a constrained optimum in production and dissemination of original works to emerge is to prevent its collapse. This collapse could result, under a more liberal than desirable interpretation of the fair dealing exception, from the withdrawal of the object for which such blanket licenses are or could be issued. Hence, it is important to consider among the effects of the dealing on the works the possibility that a liberal interpretation of the exception might lead to the destruction in whole or in part of the emerging market-like mechanisms and institutions.

Hence this analysis could be viewed as an example in the field of economic design. Hal Varian, currently Chief economist at Google and Emeritus Professor of Economics at Berkeley wrote (New York Times, August 29 2002): "Economists are increasingly being called on to give advice about how to design new economic institutions. They have been consultants in the design of auctions, power exchanges, financial exchanges and a variety of other market and market-like mechanisms. In these applications, economics looks more like engineering than it does pure science. Just as a civil engineer applies principles of physics and mechanics to design bridges, economists apply principles of economic analysis to design exchange mechanisms."

\section{The competitive response to copyright exceptions}

Following other landmark decisions of the SCC in 2012 and the revision of the Canadian Copyright Act coming into effect in November 2012, the Canadian Copyright Board (CCB) began to modify previously set royalty formulas and eat away at royalties by reducing in particular the types of reproductions that could be subject to copyright tariffs. The after-the-fact approach was contested among others by Boyer and 
Cremieux (2013) $)^{26}$ who claimed that if selling prices are lowered or production costs increased, a firm in a competitive context will need to adjust one way or another its pricing and production strategies in order to maintain its profitability, while properly compensating its resources and suppliers.

They further claimed that if a regulation imposes in such a competitive framework the noncompensation of some product or service (i.e., a zero price), then either that product or service will cease to be produced or other prices will be adjusted in order to generate sufficient revenues for the firm to provide competitive compensation to its resources, including its labor and capital, as well as to its suppliers. If the non-compensated products are produced jointly with the firm's other products, or if the non-compensated products are mandatory, then the second alternative will be more likely: the non-compensated products will continue to be produced, while the other products will be priced higher.

They concluded that economic theory would predict that setting the compensation for some copies or reproductions to zero (i.e., applying exceptions), which would prima facie reduce the royalties to rightsholders, would and should lead to higher prices/royalties for other non-exempted reproductions. Such realignment of prices or royalty rates is necessary to keep creation and the pressure on creation going, insofar as once again the level of compensation was set ab ovo, at least implicitly, with a competitive framework in mind.

The competitive response argument implies that there is in fine no economic rationale for modifying the overall amount of royalties paid to rightsholders even in the presence of exceptions. In other words, contrary to users' claims, even if new exceptions were to impose the noncompensation of certain types of music reproductions, they would not in this framework imply a reduction in royalties for the right to reproduce recorded music.

Although this competitive response argument may appear non-intuitive for non-economists, it simply says that if it had been known at the start that some reproductions were exempted, other reproductions would have been priced higher. It is clear that what matters to rightsholders is not which reproductions are and are not compensable, but the overall royalty payment is for the use of their reproduction right since all reproductions are joint products.

\section{Section 2. The Gordian Knot of Copyright Pricing/Compensation in}

\section{the Digital Era}

The most important general principles or concepts that have been present in numerous if not all decisions of the different copyright boards and authorities are the following: the economic concept of works as information assets, the socio-economic efficiency criteria, the willing buyer willing seller paradigm, the willingness to pay and the ability to pay for the rights by different users, the

\footnotetext{
${ }^{26}$ Marcel Boyer and Pierre Cremieux (2013), Measuring Appropriate Royalty Rates in the Presence of Copyright Exceptions, a report prepared for AVLA/SOPROQ and CMRRA-SODRAC Inc. (CSI) for use in the proceedings before the Copyright Board concerning their proposed Commercial Radio Tariffs, Copyright Board of Canada.
} 
concept of proxy for an inexistent price, and finally the role of the copyright boards and commissions or authorities, under different institutional settings, acting as surrogates of competitive markets and informed negotiations. ${ }^{27}$

How can we define the level of production of or investment in an information asset to ensure not only that the maximum well-being is provided to citizens but also that existing institutions (markets, competition, regulations) will be able to achieve this level of production or investment? It is a complex issue.

\section{Social efficiency: first best and second best policies}

For normal goods and services, the optimal level of consumption is generally considered to be the level achieved when the price of the good is equal to its marginal production cost, insofar as demand or total consumption of the good at this price is such that the total net surplus generated, defined as the total value of consumption less the total cost, is positive. Otherwise, it is better not to produce the good in question. Thus the optimal consumption level (production, distribution, and dissemination) is either zero or equal to the level obtained with marginal cost pricing. This level corresponds to what economists call a first-best optimum, which requires that fixed costs be covered one way or another. A competitive market is generally the preferred mechanism for defining and achieving an optimal level of production and consumption for normal goods.

With information goods or assets, the problem is somewhat more difficult since the same unit (think of a musical work or sound recording) can be listened to and enjoyed many times by many different users or consumers now and in the future as consumption does not destroy or alter the unit in question. The optimal production level will therefore involve the marginal cost and the sum of marginal values enjoyed over time by all users: as long as the former is lower than the latter, it will be welfare enhancing to produce the unit in question. And additional units should be produced as long as the sum of marginal values enjoyed over time through multiple uses by multiple users remains above the marginal cost incurred by creators as investors, hence till the point where the two are equal. Meeting such a condition is difficult as it implies, when the sum of marginal values is equal to marginal cost, that marginal values across users will differ. ${ }^{28}$

However, for an information good or asset whose marginal cost of distribution is zero or almost zero, under the digital technology revolution, the optimality condition requires that the sum of users' marginal values be equal to zero, which implies that each and every user's marginal value

\footnotetext{
${ }^{27}$ For more on this set of principles in the context of hearings and decisions of the Copyright Board of Canada, see Marcel Boyer (2011), "The Canadian Copyright Board: Economic Concepts and Principles in Decisions and Arguments", pp. 61-99 in Ysolde Gendreau (ed.), Copyright Board of Canada: Bridging Law and Economics for 20 years, Carswell, 2011.

${ }^{28}$ Achieving the optimality condition through decentralized decision making by individual users would for instance require different prices for different users in order to induce them to consume the proper quantity, each user thereby facing his own particular price (Lindhal equilibrium). The sum of those individualized prices must then be sufficient to cover the marginal cost of production.
} 
be equal to zero. Clearly, a common price equal to the marginal cost of (re)production will not enable the creator/seller/producer to generate enough revenue, in fact any revenue, to cover all costs involved in generating and marketing the information asset, and in particular the significant fixed costs, including the proper compensation for risk taking.

Indeed, the fact that the same unit of an information asset can be used or consumed by many, at the same time or not, means that the good survives consumption: the marginal cost of adding one user or consumer, or for that reason any or almost any number of additional users or consumers can be done at zero cost, almost forever.

A competitive market, which would implement the condition "price $=$ marginal cost $=0$ ", cannot therefore ensure an optimal allocation of resources unless and until the compensation of fixed costs of production or creation is achieved. With a quasi-zero price, too few individuals would be prepared to take up a career as a creator and to devote the time and resources needed to generate zero-priced information assets, namely original musical works.

In response to these problems, two streams of thought have developed. The first argues that one ought to assign property rights to creators over their created assets, in particular over the transfer and reproduction of their creations, and allow markets to emerge and determine equilibrium prices, that is, prices that ensure that creators and consumers/users are satisfied with the exchange or transaction level that would thereby be achieved.

Because of the property right conferred, creators might be able to restrict access to those users or consumers who actually pay for this access. The resulting equilibrium price would be higher than the marginal cost and could make it possible to cover all of the production and distribution costs, at the expense of lower than optimal consumption levels or use levels (second best) of the asset.

The other stream of thought argues that the strict attainment of an optimum must be promoted with transfer, reproduction and consumption allowed at marginal cost, hence free of charge (first best). Creators should then be compensated in various ways from some combination of private sponsorship and grants, concerts with limited admission capacity hence priced above zero, and government subsidies.

Each of these approaches poses problems.

Overly strict copyright provisions could give the producers of the work a monopoly over the asset, or group of assets if creators can regroup under a common roof: the price of each unit could then be too high and the number of creations distributed or disseminated too low, that is, less than optimal because of the resulting limited access to and distribution of the works, thereby reducing the production of new works as each new work is in some sense the indirect result of previous works: "A dwarf sitting on a giant's shoulders can see much farther than the giant." 29

\footnotetext{
${ }^{29}$ Jean de Salisbury (1159), Metalogicon, University of California Press (1955 edition), 305 pages: "Bernard of Chartres used to say that we are like dwarfs on the shoulders of giants, so that we can see more than they, and things at
} 
Free use has its own set of problems. If an organization of private parties or governments had to fund the production of works through fixed or variable grants to creators and to that effect keep a record of every use, how could it establish the absolute and relative value of the works produced in order to properly compensate creators? The organization might want to control its disbursements, reduce them or even link them to arbitrary factors, to the detriment of creators and users. Which and how many authors or creators would spend time and resources to produce quality works whose valuation depends on the goodwill and sagacity of some organization of private parties or government bureaucracies?

Economic analysis can provide or at least suggest answers to these questions. The problem is complex, as Cooter and Ulen (1998) ${ }^{30}$ suggested: "Put succinctly, the dilemma is that without a legal monopoly not enough information will be produced but with the legal monopoly too little information will be used." Obviously, solutions will not be completely efficient or first-best optimal.

In other words, as Lenard and White $(2015)^{31}$ phrase it: "Musical works are classic examples of 'information goods'. Such goods are characterized by large (and sunk) 'first-copy' costs and very low - even zero - costs of reproduction. This suggests that optimal prices would not be based on costs anyway, but instead would be based on demand characteristics. If fixed costs are non-trivial and if marginal costs are constant with respect to the volume of output, then the 'first-best' system of pricing from a social efficiency perspective - prices should be equal to marginal costs - will not allow the sales revenues to cover those fixed costs. A 'second-best' alternative to cover those fixed costs, with the least distortion of social efficiency, should be sought."

The whole art lies in finding a solution that can be useful and be implemented at low cost while at the same time come close to an optimal allocation. The best that one can hope for would be to regulate market pricing in order to minimize distortions from the first-best solution, that is, to introduce appropriate distortions-minimizing wedges between prices and marginal costs to meet a budget objective, which in the present context takes the form of a proper competitive compensation level for creators.

\section{A combination of the above.}

The first-best solution is to price at marginal cost and find other ways than revenues generated from sales to compensate creators, as those revenues will not be sufficient to do so. The secondbest solution is to introduce wedges between prices and marginal costs in the different market

a greater distance, not by virtue of any sharpness of sight on our part, or any physical distinction, but because we are carried high and raised up by their giant size."

\footnotetext{
${ }^{30}$ Robert Cooter and Ulen, Law and Economics, HarperCollins Publishers, 1998.

31 Thomas M. Lenard and Lawrence J. White (2015), “Moving Music Licensing into the Digital Era: More Competition and Less Regulation,” Technology Policy Institute, Washington, December.
} 
segments, or at different links in the chain between creators and users or consumers, in such a way that the resulting use or consumption levels allow the proper compensation of creators but diverge as little as possible form the first-best ones.

This can be done through what economists call the "Ramsey inverse elasticity principle" or pricing rule: wedges between prices and marginal costs should be inversely proportional to the elasticity of demand, that is, be higher when demand is less elastic, indicating a low reactivity of users or consumers to price increases. In this way, second-best consumption levels will remain as close to first-best levels as possible given the budget constraint.

One may also think of a combination of the above two solutions: partly first-best principled and partly second-best principled. The problem and its solutions are complex and it is important to remember that as soon as one enters into a realm of solutions that have imperfect and incomplete information bounds or constraints placed upon them, the best becomes the enemy of the good: things gets messy when "you run with the hare and hunt with the hounds."

\section{The creators' compensation as the budget constraint to be covered}

What should be the creators' compensation constraint to impose on the overall pricing system? That is another Pandora's Box. The historical prices and royalty revenues effectively received by rightsholders are of little help here as they were obtained and developed through self-referencing rate determination procedures and hearings, with little if any theoretically-sound empirical justifications.

It is the competitive market value of copyrights in music that provides the compensation constraint to be imposed on the overall pricing system. Since musical works and sound recordings are information goods or assets, the competitive market value of copyrights, hence the determination of relevant tariffs, rests not so much on the cost of creation, which is underlying the supply function of new works and new sound recordings, but rather on the value of such goods for the users. ${ }^{32} \mathrm{We}$ thus need a more rigorous basis and more rigorous analytical tools for ascertaining the competitive market value of copyright in copyrighted works or assets. ${ }^{33}$

\footnotetext{
32 The Canadian Copyright Board recognized, in its 2002 Pay Audio Decision, that: "in information industries, pricing tends to be based on the value to the buyer, not on cost to produce" (page 8).

${ }^{33}$ One striking example of the difficulty of discovering/finding/setting a price and of the immense importance of doing it for "unusual" goods is provided by the pricing of financial options, more generally derivatives. No one had been able to "value" those complex financial instruments until the early 1970s. Although there was a potential demand (a need) and a potential supply and although transactions on financial options (barely) existed since ancient times (see Geoffrey Poitras, "The Early History of Option Contracts", chapter 18 in W. Hafner and H. Zimmermann (eds.), Vincenz Bronzin's Option Pricing Models: Exposition and Appraisal, New York, Springer-Verlag (2009): 487-518; and Phelim and Feidhlim Boyle, Derivatives: The Tools That Changed Finance, Risk Books, 2001), the options market was still virtually nonexistent in the mid-70s. The market was born and came alive some ten years after three mathematical economists, students of Paul Samuelson (Fischer Black, Myron Scholes, and Robert Merton), had published in 1973 a formula for determining the competitive equilibrium price of an option (Fischer Black and Myron
} 


\section{Section 3. The Search for the Competitive Market Value of Music}

Pricing copyrighted works or assets has always been a difficult task given the information good character of such works. Doing it in the digital era is even more challenging. In a recent paper, ${ }^{34} \mathrm{I}$ propose an approach to characterizing the proper competitive market value of copyrights in music. The approach infers the competitive market value of copyrights in music, hence the competitive market compensation of rightsholders, from the observation of the behavior and choices made by operators of Hertzian radio, satellite radio (SiriusXM), and interactive music streaming services (Spotify). The approach does not rely on traditional path-dependent heuristics and rules of thumb, which represent the bulk if not the totality of current procedures to determine royalties and whose foundations in theoretical and applied economics are relatively weak and clearly inadequate to tackle the current and upcoming challenging copyright agenda.

I stress the important link between the competitive market value of music and the ensuing fair compensation of creators, which corresponds to what would be paid on well-functioning competitive markets. A competitive equilibrium is a situation in which economic forces are balanced at a stable resting point suitable for both willing buyers (demand) and willing sellers (supply). Therefore, a competitive equilibrium price or a properly negotiated price would necessarily account for balance between creators' interests and users' interests since any investments, costs, risks, and derived benefits would be incorporated in the resulting competitive market or negotiated price.

In spite of the fact that musical works are different from standard goods like apples or cars - they are information goods -, the same fundamental principles apply. However, two possibilities arise: either users pay the same price regardless of the value they derive from the work or users pay some proportion of the value they derive from the good (Lindahl pricing). And a negotiated price between sophisticated and symmetric parties is analogous to a competitive equilibrium price.

The results derived in that paper suggest that rightsholders are significantly shortchanged and poorly served by the current copyright pricing or royalty framework, to the annual tune of billions of dollars.

In the paper, I derive three propositions or theorems:

1. In Hertzian radio (HR), the competitive market values/compensations/prices of music and talk are necessarily proportional to their "shares" of broadcast time.

Scholes, "The Pricing of Options and Corporate Liabilities," Journal of Political Economy, Vol. 81, No. 3 (May Jun., 1973), pp. 637-654; Robert C. Merton, "Theory of Rational Option Pricing," The Bell Journal of Economics and Management Science Vol. 4, No. 1 (Spring, 1973), pp. 141-183). The worldwide "size" of the market for options and other derivatives went from a notional value of virtually zero to some 600 trillion US dollars for OTC derivatives only in 2015 (BIS Quarterly Review): mind-boggling numbers.

${ }^{34}$ Marcel Boyer (2017a) referenced at footnote 4. 
2. In satellite radio (SR such as SiriusXM), the competitive market values/compensations/prices of music and other inputs are necessarily proportional to their relative capacities to attract subscribers/listeners.

3. In interactive music streaming services industry (Spotify), the competitive market value/compensation/price of music is the arm's length negotiated per-play rate, which includes a premium for interactivity

\section{Cost Structures and Royalty Formulas}

I stress in the paper that differences in cost structures, namely cost of entry and cost of audience reach, favor different royalty formulas in different industries although those industries compete with each other up to a certain point for listeners' ears. It is important to maintain a level playing field of competition between different technologies and industries.

In HR and SR industries, costs of entry (broadcasting spectrum license) and fixed costs of audience reach (broadcasting equipment) are relatively high while marginal costs of audience reach are relatively low, even zero. This favors a percentage of revenues formula. In music streaming or webcasting services industry, costs of entry are relatively low while fixed and marginal costs of audience reach (bandwidth costs) are relatively high and increasing with audience size. This favors a per play rate formula.

Hence, a royalty formula expressed as a percentage of revenues through a blanket license for repertoires is socially efficient for $\mathrm{HR}$ and SR, while a royalty formula expressed as a per play rate is socially efficient for interactive and semi-interactive music streaming and webcasting services. Per play rates in webcasting and music streaming services allow rightsholders to avoid being "residual payees" and favor healthy competition first by eliminating uncompetitive or inefficient webcasters who use huge amount of recorded music with little revenue generating capacity, and second by reducing destructive competition intensity (Bertrand trap). A per play formula thus induces webcasters, as resellers of recorded music, to develop value added features such as the interactivity (Spotify) or genomic features (Pandora).

\section{The Competitive Market Values}

As mentioned above, I show in the paper that for commercial terrestrial/Hertzian radio, the relative competitive market values of music and talk are necessarily proportional to their respective shares of program time. Using data obtained for the Canadian context, I obtain that the competitive market value of music is equal to $28 \%$ of revenues. And, as mentioned above, it is socially efficient that royalties be expressed as a percentage of revenues.

I show also that for satellite radio, the relative competitive market values of music and talk are necessarily proportional to their relative capacities to attract subscribers. In the case of US SR (SiriusXM), this competitive market value is equal also to $28 \%$ of revenues. And it is socially efficient that royalties be expressed as a percentage of revenues. 
Finally, I show that for interactive online music streaming services, the competitive market value of music corresponds to the mainly unregulated negotiated royalty payments (per-play rate) paid by interactive music streaming services, including the premium for interactivity. In the case of interactive

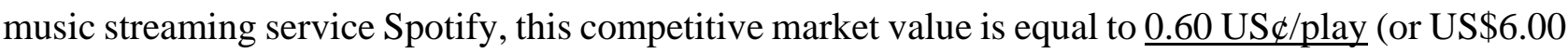
per 1000 plays). In the case of semi-interactive music streaming service Pandora, this value is equal to $\underline{0.31}$ /play (or US\$3.13 per 1000 plays). And it is socially efficient that royalties in semi-interactive and interactive webcasting be expressed as a per play rate.

All three value estimates, qualifying as competitive market values, were obtained independently from observing the behavior and choices of operators / users, not from value judgments. They nevertheless point to similar or compatible competitive market values! To verify if the above royalty formulas and rates satisfy the competitive level playing field principle, I translate them into royalty rates and payments that can be compared with each other.

The $28 \%$ of revenues competitive market values of music in the Canadian $\mathrm{HR}^{35}$ industry corresponds to a per play rate of between $0.235 \mathrm{C} \notin /$ play, based on Audley and Boyer (2007) ${ }^{36}$ program time estimates, and $0.324 \mathrm{C} \notin /$ play, based on averaging program time estimates of five different reports. ${ }^{37}$ These per play rates can be directly compared to rates paid by non-interactive or semi-interactive music streaming services.

Semi-interactive service Pandora paid in 2016 a per play rate of $0.245 \mathrm{US} \varnothing /$ play while its competitive market value rate, based on Spotify rate less the premium for interactivity, should be 0.31 US $\varnothing /$ play. I conclude therefore that the competitive market value of music on Pandora is somewhat of the same

\footnotetext{
${ }^{35}$ I do not have the number of plays on satellite radio SiriusXM.

${ }^{36}$ Paul Audley and Marcel Boyer (2007), "The 'Competitive' Value of Music to Commercial Radio Stations," Review of Economic Research on Copyright Issues 4(1), December 2007, 29-50

https://papers.ssrn.com/sol3/papers.cfm?abstract_id=1144286 [reprinted in Audhi Narayana Vavili (ed.), Music Copyrights: A Legal Wrangle, Amicus Books, 2009; translated in Spanish "El valor competitivo de la musica para las estaciones de radiocomerciales", In Watt, R. (Ed.), Teoría econnómica y derechos de autor (205-244). Datautor, Madrid (2011); and extensively reviewed in the PriceWaterhouseCoopers (Australia) Report, Valuing the use recorded music, July 2008. See also Marcel Boyer (2015), The Value of Copyrights in Recorded Music: Terrestrial Radio and Beyond, Commentary \#419, C.D. Howe Institute, Toronto, February 2015. https://www.cdhowe.org/sites/default/files/attachments/research_papers/mixed/Commentary_419.pdf

37 Those estimates include the following obtained through different methodologies applied to different periods, different contexts, and different samples: $(70 \%, 30 \%)$ in Steven Globerman (2007), "Determining the Appropriate Increase in SOCAN Tariff Payable for the Public Performance of Musical Works," a report filed on behalf of the Canadian Association of Broadcasters (CAB-6) for the 2007 commercial radio hearings, Copyright Board of Canada; (81\%, 19\%) in Erin Research (2008), "The Use of Music on Commercial Radio, 2008 Sounds Recordings as Feature Content on Music Stations", a report filed on behalf of CSI (CSI-03.L), for the 2008-2009 commercial radio hearings, Copyright Board of Canada; $(81 \%, 19 \%)$ in Copyright Board of Canada (2014) Decision on "Re:Sound No. Tariff 8 - Noninteractive and semi-interactive webcasts, 2009-2012."; (67\%, 33\%) in David Touve (2015), "\$0.0000955: The value of a Spin, per Listener, to Songwriters on US Radio in 2014; and Audley and Boyer (2007) referenced in footnote 36. The Canadian HR industry currently pays about C\$ 100 million per year (C\$ 180 million before deductions) in music royalties, which corresponds to $0.052 \mathrm{C} \notin /$ play (Audley and Boyer 60/40) or 0.044 C $\notin /$ play (AVG5 71/29) or 0.039 C $\notin /$ play (Board's 2014 81/19). Therefore, the Canadian HR industry currently pays between $0.039 \mathrm{C} \phi /$ play and $0.052 \mathrm{C} \notin / \mathrm{play}$.
} 
order as the competitive market value of music in HR (and SR), before adjusting for the exchange rate, which is a rather interesting and somewhat unexpected result.

To be comparable with the interactive music streaming services royalty rate, the above HR rates must be adjusted upwards for the value of interactivity ( $+92 \%$ from music downloads ${ }^{38}$ ), which takes us to a range of $0.451 \mathrm{C} \phi /$ play (Audley and Boyer) to $0.607 \mathrm{C} \phi /$ play (average of the five different reports). The interactive streaming service Spotify paid in 2015 a per play rate of $0.600 \mathrm{US} \phi / \mathrm{play}$, which is somewhat of the same order, before adjusting for the exchange rate, which again is a rather interesting and somewhat unexpected result.

A note on YouTube (Google) may be useful here. According to the Recording Industry Association of America (RIAA), which represents the major music companies, YouTube pays actually about 0.1 US $₫$ /play in royalties. As Cary Sherman, Chairman and CEO of RIIA, puts it: "it makes no sense that it takes a thousand on-demand streams of a song for creators to earn $\$ 1$ on YouTube, while services like Apple and Spotify pay creators $\$ 7$ or more for those same streams." 39 YouTube claims on the other hand that it is advertising-based and therefore more comparable to HR radio than to subscription-based interactive webcasting like Apple Music and Spotify. Recall that the Canadian HR industry pays actually between $0.039 \mathrm{C} \notin$ /play and $0.052 \mathrm{C} \notin /$ play, ${ }^{40}$ while Apple Music pays about 1.2 US $\notin /$ play, Spotify 0.6 US $\varnothing /$ play (although the RIAA claims that Spotify pays closer to 0.7 US $\notin$ /play), and Pandora 0.245 US $\notin /$ play. The Phoenix Center claims that "Using 2015 data ... a plausible royalty rate increase [on YouTube, based on an average royalty rate between non-interactive streaming and interactive streaming rates] could produce increased royalty revenues in the U.S. of $\$ 650$ million to over one billion dollars a year."41

\footnotetext{
${ }^{38}$ See Marcel Boyer, Joel Blit and Paul Audley (2013), "The Value of the Use of the CSI Repertoire by Online Music Services," a report filed as Exhibit CSI-3 in the case CSI Online Music Services (2011-2013), SOCAN Tariff 22.A Online Music Services (2011-2013), SODRAC Tariff 6 - Online Music Services, Music Videos (2010-2013), Copyright Board of Canada.

39 https://medium.com/@RIAA/2016-a-year-of-progress-for-music-4e9b77022635

${ }^{40}$ See footnote 37 above.

${ }^{41}$ The Phoenix Center (2017) referenced in footnote 7.As the authors put it: "For on-demand subscription streaming services, RIAA reports retail revenues of $\$ 1.2$ billion, from which we estimate royalties of $\$ 670$ million. This platform delivered about 85.3 billion plays, so the average retail price is $\$ 0.014$ per play and the implied average royalty is \$0.0079 per play [D. Johnson, See How Much Every Top Artist Makes on Spotify, TIME (November 18, 2014) (available at: http://time.com/3590670/spotify-calculator); T. Nath, How Pandora and Spotify Pay Artists, INVESTOPEDIA (October 28, 2015) (available at: http://www.investopedia.com/articles/personalfinance/121614/how-pandora-and-spotify-pay-artists.asp); P. Kafka, Here's What Happens to Your \$10 After You Pay for a Month of Apple Music, RECODE (June 15, 2015) (available at: http://www.recode.net/2015/6/15/11563558/hereswhat-happens-to-your-10-after-you-pay-for-a-month-of-apple-music); V. Luckerson, Here's How Much Money Top Musicians Are Making on Spotify, TIME (December 3, 2013) (available at: http://business.time.com/2013/12/03/hereshow-much-money-top-musicians-are-making-on-spotify)]. Based on RIAA revenue reports, we estimate there were $\$ 588.5$ million in statutory services royalties in 2015, but RIAA does not report retail revenues. We use Pandora, the largest of the statutory streaming services, to approximate retail revenues. We estimate that Pandora delivers about 240 billion plays for which it received revenues of $\$ 1.15$ billion in 2015 . Thus, the average retail "price" is $\$ 0.0047$ per play in 2015. The volume for the entire statutory streaming platform is estimated at 340.5 million plays, so the platform revenues are estimated to be about $\$ 1.6$ billion [Pandora Form 10K (2016)]. Based on this play count, the effective
} 


\section{The missing royalties}

The implied change in royalties is significant. In the Canadian HR industry case, the competitive market value of music is 4.5 times larger than the current level of royalty payments: $28 \%$ versus $6 \%$, or C\$ 450 million versus C\$100 million. In the US SR industry (Sirius XM), the competitive market value of music is 2.8 times larger than current royalty payments: $28 \%$ of revenues versus $10 \%$, or US\$ 1.28 billion versus US\$ 457 million. In non-interactive webcasting (Pandora), the competitive market value of music is about $28 \%$ larger than current royalty payments: $0.312 \mathrm{US} \notin /$ play versus $0.245 \mathrm{US} \notin /$ play, or US\$ 937 million versus US\$ 734 million. In all these cases, royalty rates are determined or strongly influenced by regulatory bodies. In the interactive music streaming industry (Spotify), it may be considered to be at the proper level (0.600 US $\notin /$ play), given the mainly unregulated negotiation process between users and rightsholders (music labels) in that industry. ${ }^{42}$

This begs the questions: Where are the missing values? If Governments and their royalty-fixing authorities (copyright boards and commissions) design and implement rules, regulations and exceptions that significantly reduce competitive market value tariffs, thereby expropriating part of rightsholders' assets, who should pay for such policies?

It is difficult to generalize the results across different jurisdictions as copyright structures differ across jurisdictions (See Appendix). A rough but realistic figure of rightsholders' under compensation, as compared to the competitive market value of their works and rights, runs to billions of dollars per year. ${ }^{43}$ This begs the question: How to and who should fill the shortfall?

royalty is $\$ 0.0017$ per play, which is consistent with a blend of statutory rates in 2015 (the range is $\$ 0.0014$ per play to $\$ 0.0025$ per play, depending on the nature of the statutory service)" (page 14) and "In 2015, several analysts estimated that YouTube paid $\$ 741$ million globally to rightsholders for the consumption of their music, a number that appears well below market compensation from one of the world's largest music delivery platforms [M. Mulligan, State of the YouTube Music Economy, MIDiA (July 2016) (available at: https://www.midiaresearch.com/blog/the-state-of-theyoutube-music-economy); T. Ingham, Youtube Earnt \$9bn in Revenue Last Year, Towering Over Spotify, MUSIC BUSINESS WORLDWIDE (January 5, 2016) (available at: http://www.musicbusinessworldwide.com/youtube-willearn-9bn-in-revenue-this-year-towering-over-spotify)]. Most of this royalty revenue comes from a split of YouTube's advertising revenue with artists and labels rather than the fixed per-play royalty typically seen for streaming services (both subscription and ad-based). A percentage of advertising revenue - especially if either the percentage is low or the ad revenues are low - may be inadequate compensation for the use of music. Just because an advertising platform cannot generate large advertising revenues does not imply it should pay very little for the heavy use of music. Indeed, the worse the business plan, the less is paid for music under such a scheme. Recognizing the potential for such perverse outcomes, market negotiations for the rights to sound recordings typically include some type of per-play royalty (in addition to revenue sharing) to avoid under-compensation from business plans that generate too little revenue" (pages 56). On safe harbour provisions of DMCA, see http://www.hypebot.com/hypebot/2017/01/youtubes-safe-harbor.html

${ }^{42}$ Globally, the interactive music streaming industry pays close to $0.8 \mathrm{US} \not /$ play (see footnote 44 above).

${ }^{43}$ As Cary Sherman of RIIA puts it (https://medium.com/@ RIAA/2016-a-year-of-progress-for-music-4e9b77022635): "Collectively, it feels like a rigged system [combining outdated music licensing and copyright laws, ISP companies, and government officials at many levels] that: leaves artists, songwriters and labels with little control over the monetization of their work; results in royalty rates that are tiny fractions of a penny per stream; threatens to undermine the potential for further growth from subscription services, which is what is powering the positive news about the business; imperils the $\$ 4.5$ billion that record labels spend globally on discovering, investing in and promoting artists; jeopardizes the digital 
The much needed transformations of music licensing and copyright laws and regulations as well as the social responsibility of covering the creators' compensation for the valuable assets they own and make available for the well-being of all could be undertaken along the lines developed in the next paragraphs.

\section{The Economics of Public Policy toward Culture: The Elephant in the Room}

The fundamental element of a public policy towards culture insofar as compensation of creators is concerned is to identify different royalty mechanisms (rates / percentages / prices / grants, bases) to ensure a maximal dissemination of copyrighted works/assets, while ensuring a fair and equitable or competitive compensation of creators, that is, to combine first best and second best mechanisms.

Since it is difficult and possibly non-efficient and non-optimal to charge directly end consumers for the music they consume given the information good character of musical works and sound recordings and the significant value generating properties of digital technologies through low cost dissemination and customization, we must find other complementary ways to compensate rightsholders for the competitive market value of their created works/assets.

One possibility to achieve the competitive market compensation of creators might be to bring all "beneficiaries" (primary users, ISP, equipment manufacturers, end consumers, and Governments) into one class or group of users and to make that group as a whole jointly and severally responsible for ensuring the proper competitive market compensation of creators. Those beneficiaries would be responsible for finding a sharing formula to determine their respective contributions to foot the bill. It is equivalent to considering a chain of stakeholders (users) between the creators and the end consumers of music, a complex endeavor. This chain of beneficiaries represents the elephant in the room, alongside rightsholders and direct users.

That is a difficult problem, never properly addressed before. The standard analytical framework considers only two stakeholders, creators and users/consumers. We could reformulate this analytical framework as a two-stage procedure. In the first stage, only two stakeholders' groups would be considered: creators on one side and a single group of users or beneficiaries on the other side. In the second step, the latter group would be disaggregated into a number of beneficiaries responsible for honoring the liabilities of the single group of users in the first stage. The two-step formulation appears to be a less complex approach to rein in the elephant.

\section{Conclusion}

A solution can be found that is properly grounded in the economics of efficient allocation of resources, efficient negotiation/mediation, and cooperative game theory. It can be done, but needs

innovation and entrepreneurialism that's revolutionizing music for consumers; and takes money directly out of the paychecks of thousands of artists and songwriters." 
some analysis. It is challenging to develop the proper theoretical argument and to write it in a userfriendly and convincing way.

The sought-after solution to this problem would involve the design of tariffs or contributions imposed at different stages of the value chain between creators and end consumers, hence on different beneficiaries of copyrighted musical assets, those beneficiaries being once again the direct users and ISP, equipment manufacturers, end consumers, as well as Governments as the collectives of end consumers. If indeed music fuels the Internet and is leading the digital transition, such a program is urgently needed.

It might be useful to recall here that in the context of public policies towards educational services there is a clear separation between the pricing of services to end users, the students and their parents, and the compensation of educational services / content providers namely teachers and administrators and other personnel who are arguably compensated at their competitive market value.

Similarly in public policies towards healthcare, there is a clear separation between what end consumers, the patients, pay and what the providers of healthcare services/content namely doctors, nurses, administrators and other personnel are receiving as compensation, which arguably correspond to their competitive market value. 


\section{Appendix - The Structure of Rights in Music: a Brief Survey}

The above analysis and proposition dealt with the overall value of copyright in musical works and sound recordings. In reality, copyright royalties are determined through a somewhat decentralized system of negotiations and rate setting hearings.

In the musical industry namely terrestrial/Hertzian radio, Internet or non-interactive radio, and streaming or interactive services, as well as the direct sale of music on physical supports (CDs and others) or digital downloads, there are basically two copyrights, a performance right and a mechanical (reproduction) right, and two broad groups of rightsholders, a first group comprising authors, composers and music publishers who own the performance and mechanical rights in musical works or compositions, the so-called original or longtime rightsholders, and a second group comprising the performers and the makers of sound recordings (record labels) as well as other non-featured artists and musicians who own the performance and mechanical (reproduction) rights in the sound recordings, the so-called new or neighboring rightsholders (in most jurisdictions since the end of the 1990s).

Each of the four combinatory subsets, each subset being composed of one copyright and one group of rightsholders, is typically occupied by one or more Collectives in charge of representing the relevant rightsholders in negotiations or rate setting hearings before courts or regulatory bodies.

In the following paragraphs, the cases of US and Canada are first explicitly presented, followed by a discussion of different cases in European countries, namely France, Germany, United Kingdom and Spain. As we will see, the copyright landscape differs between jurisdictions: not all combinatory subsets are present in a given industry across jurisdictions and care must be exert when comparing royalties or rates between those jurisdictions.

In the following tables,

- "----" stands for the absence of a Collective organization responsible for collecting and distributing royalties, in which case rightsholders (such as music publishers and record labels) negotiate licenses and royalties directly with users if and when a right can be exercised.

- "N.A." stands for the explicit absence of a right to be exercised, because of a legal regulatory statute for instance.

- "I" stands for the first group of rightsholders as defined above, that is, authors, composers and music publishers (rights in musical works or compositions).

- "II" stands for the second group of rightsholders as defined above, that is, performers and record labels, as well as non-featured artists and musicians (neighboring rights in sound recordings). 


\section{The USA ${ }^{44}$}

1. Terrestrial radio, live venues, and other public places (clubs, restaurants, etc.)

\begin{tabular}{|c|l|l|}
\hline Rights $\Downarrow$ Rightsholders $\Longrightarrow$ & II \\
\hline Public Performance & $\begin{array}{l}\text { PRO: ASCAP, BMI, } \\
\text { SESAC, GMR }\end{array}$ & N.A. \\
\hline Mechanical (Reproduction) & N.A. & N.A. \\
\hline
\end{tabular}

PRO is the acronym of Performance Rights Organization. To avoid an exercise of market power by PROs, BMI and ASCAP are governed by consent decrees, which means that a "rate-court" can set the rates (per radio play, per stream, etc.) if no agreement between parties is reached. Hence the rate court is ultimately fixing the rate in any case. BMI and ASCAP are responsible for collecting performance royalties for musical compositions. In exchange for the power to collect on behalf of songwriters (authors and composers) across the land, they can only negotiate under the umbrella of this rate court. ${ }^{45}$

The ASCAP and BMI consent decrees were enacted in 1941 as a resolution to antitrust cases brought up against the PROs. The decree maintained the PROs and therefore recognized implicitly the capacity of a PRO to efficiently reduce transaction costs in contracting and monitoring for both rightsholders and users. ${ }^{46}$ The decrees (including subsequent modifications) restricted ASCAP's and

${ }^{44}$ https://www.futureofmusic.org/article/article/music-and-how-money-flows

${ }^{45} \mathrm{https}: / / \mathrm{www}$.royaltyexchange.com/learn/music-royalties/

46 A long convincing if sobering quote from Lenard and White (2015) illustrates this point: "In the absence of PROs, publishers and other copyright owners would have to interact directly with users and distributors such as bars and restaurants, radio stations, and digital services. The number of transactions would be enormous. However, the terrestrial broadcast radio industry bargains collectively with ASCAP and BMI through the Radio Music License Committee (RMLC). Similar collective negotiation occurs between the Television Music Licensing Committee (TMLC) and the PROs. With PROs in the middle, each of the entities (and both side $s$ of the transaction) only has to deal with the two organizations - ASCAP and BMI- for the composition rights for most music (and with SESAC and GMR for a much smaller amount) and, for non-interactive digital services, with SoundExchange for the administration of sound recording rights. The PROs themselves are able to take advantage of economies of scale in negotiating licenses, monitoring licensees, and collecting and distributing royalties. Transactions costs are further minimized through the use of the blanket license. The collective negotiation of rights, however, creates market power issues: ASCAP and BMI, for example, control the overwhelming majority of music composition performance rights in the United States. This market power is (in principle) limited by the consent decrees (as modified over the years) and the antitrust rate court, which determines rates if negotiations fail. Similarly, SoundExchange has antitrust immunity, which enables it to represent the record labels with respect to sound recording rights. By setting rates for statutory licenses, the CRB is a check on the actual or potential market power of copyright owners. Some licenses are negotiated without the benefit of a PRO intermediary, which suggests that the severity of the transactions cost issue differs depending on the license and on the parties that are involved. Interactive digital services, such as Spotify, are not covered by the CRB ratedetermination process and negotiate directly with the record labels. Interactive services also pay royalties for mechanical rights (that non-interactive services are not required to pay), which reflects the belief that interactive services are a substitute for the actual purchase of the recording. Increasingly, as discussed below, distributors that 
BMI's capacity to negotiate and made the Federal District Court for the Southern District of New York an effective regulator or arbitrator responsible to hear the parties in negotiations, namely the PROs and user groups as would-be licensees, and set the terms of licenses including royalties to be paid for the use of musical works.

In the late 1990s, the US Congress enacted two Acts, the Digital Performance Right in Sound Recordings Act (DPRA) of 1995 and the Digital Millennium Copyright Act (DMCA) of 1998, which expanded copyright protection to sound recordings, both the public performance right and the mechanical (reproduction) right, when music is delivered through certain digital audio transmissions, such as the emerging satellite services (Sirius and XM) as well as forthcoming Internet-based radio and streaming services (Pandora, Spotify, and many others). Those acts made the licensing of music compulsory for non-interactive digital services.

Terrestrial radio do not compensate the second group of rightsholders when broadcasting overthe-air performers' performances and sound recordings. This arrangement is the result of a longstanding argument made by terrestrial broadcasters that performers and music labels benefit from the free promotion received through radio play. Broadcasters contend that airplay increases album sales, which leads to compensation for performers and record labels. As a result, broadcasters have been able, for decades, to convince Congress that they should be exempted from paying the public performance royalty for sound recordings.

But the broadcasters' argument is steadily losing relevance as album sales plummet, and their exempted status becomes more questionable and challenged when compared to other countries' broad requirements for performance royalties. ${ }^{47}$

2. Internet radio (non-interactive or semi-interactive* webcasters like Pandora, Songza, Galaxie Mobile, plus over 2500 other services, and satellite services like Sirius and XM, now SiriusXM)

\begin{tabular}{|c|l|l|}
\hline Rights $\downarrow$ Rightsholders $\Longrightarrow$ & II \\
\hline Digital Performance & $\begin{array}{l}\text { PRO: ASCAP, BMI, } \\
\text { SESAC, GMR }\end{array}$ & PRO: SoundExchange \\
\hline Mechanical (Reproduction) & ---- & ---- \\
\hline
\end{tabular}

* A non-interactive webcast refers to a stream over which the recipient exercises no control over the content of the signal or the time of the transmission. A semiinteractive webcast enables only the (near) real-time communication of the streamed

would be covered by a statutory license, such as non-interactive services, are negotiating directly with record labels and publishers."

${ }^{47}$ See The Future of Music Coalition 2013 at https://www.futureofmusic.org/article/fact-sheet/public-performance-rightsound-recordings 
content, but allows recipients to exert some measure of influence over the content or timing of the webcast.

SoundExchange isn't governed by a consent decree, which means that it can negotiate on the free market. Recording artists are not compensated when their performances are played on AM/FM radio (because as stated above there's no performance right for recordings on terrestrial radio), but they are typically paid at least five times more than songwriters and composers when music is performed digitally, like on Pandora. ${ }^{48}$ That's because of SoundExchange's negotiation power and BMI/ASCAP's legal antitrust limitations. AM/FM broadcasters do pay songwriters (more precisely authors, composers and music publishers), although at a royalty rate ultimately set by the courts. ${ }^{49}$ SoundExchange, the PRO established by the Digital Performance Right in Sound Recordings Act (DPRA) of 1995, distributes the royalty payments directly to performers (45 percent), to the sound recording copyright owners, most often the record label (50 percent), and to non-featured artists and performers ( 5 percent). ${ }^{50}$

3. Music streaming services (permanent downloads, interactive* streaming services such as Spotify, Rdio, Apple Music, Google Play, Deezer, Tidal)

\begin{tabular}{|c|l|l|}
\hline Rights $\Downarrow$ Rightsholders $\Longrightarrow$ & II \\
\hline Digital Performance & $\begin{array}{l}\text { PRO: ASCAP, BMI, } \\
\text { SESAC, GMR }\end{array}$ & PRO: SoundExchange \\
\hline Mechanical (Reproduction) & HFA (now SESAC) & ---- \\
\hline
\end{tabular}

* An interactive communication is any form of streaming where a specific sound recording can be listened to at a time and place of the recipient's choosing. This includes services such as Spotify and Rdio.

HFA (Harry Fox Agency) issues mechanical licenses for products manufactured and distributed in the U.S. A mechanical license grants the rights to reproduce and distribute copyrighted musical

\footnotetext{
${ }^{48}$ Some observers claim that Pandora pays about 10x more royalties to SoundExchange than to PROs representing authors, composers and publishers of musical works, the latter being covered by consent decrees (rates determined by "rate court" judges). See for instance http://aristake.com/post/what-is-soundexchange-ascap-bmi-pros-hfa-mechanicalsand-how-to-get-all-your-royalties

${ }^{49} \mathrm{https}: / / \mathrm{www}$.royaltyexchange.com/learn/music-royalties/. Royalty Exchange is a form of Stock Exchange for royalties, as one can read on their website: "Founded in 2011, Royalty Exchange started after identifying the need for a centralized marketplace where royalty owners could monetize their royalties and investors seeking to purchase alternative assets could invest in them. Our mission is simply to provide a platform where all types of royalty assets, such as music, television and film or patents, intellectual property, and mineral rights, can be bought or sold in an effort to bring value to both the investor and seller."

${ }^{50}$ See The Future of Music Coalition 2013 at https://www.futureofmusic.org/article/fact-sheet/public-performanceright-sound-recordings
} 
compositions (songs) for use on CDs, records, tapes, ringtones, permanent digital downloads, interactive streams (Spotify), and other digital formats supporting various business models. Spotify pays as royalties about $10 \%$ of its revenues to songwriters and publishers I (covering both performance and mechanical rights, whose rates are set by the government or the rate court, and $60 \%$ of its revenues to record labels II, through arm's length negotiations with SoundExchange.

\section{Rate or Price setting/regulating Organization}

As mentioned above, performance rights collective organizations BMI and ASCAP are governed by consent decrees, which means that royalty rates can be set by a "rate-court" if necessary. BMI and ASCAP collect songwriting performance royalties for group I, but they are limited in their ability to negotiate by this rate court. Hence, AM/FM broadcasters do pay songwriters, but at a royalty rate ultimately set by the courts.

As Lenard and White (2015) put it: “The Digital Performance Right in Sound Recordings Act (DPRA) of 1995, and the Digital Millennium Copyright Act (DMCA) of 1998, which expanded copyright protection to public performances of sound recordings through certain digital audio transmissions ... also mandated compulsory licensing for non-interactive digital services. The rates that most digital services pay for sound recording performance rights under the compulsory license are determined by the Copyright Royalty Board (CRB). Royalties are collected and distributed by a new PRO, SoundExchange. SoundExchange also participates in CRB proceedings on behalf of the copyright holders. The CRB applies different standards in determining rates for different categories of digital services. Interactive digital services (e.g., Spotify) are exempted from the CRB process (which means that these services negotiate directly with the performing artists and labels). Terrestrial radio broadcasting is free of the necessity to seek such licenses at all ... and thus 'pay' a rate of zero".

As Strickler (2015) put it: "In section 114 ratemaking proceedings before the CRB, the principal adverse parties are SoundExchange, which is the administratively-approved licensor collective, appearing on behalf of the record companies and other copyright owners; and the services/licensees that transmit sound recordings, whether pureplay non-interactive webcasters or non-interactive simulcasters on the Internet of terrestrial radio performances of sound recordings". 


\section{CANADA}

1. Terrestrial radio, live venues, and other public places (clubs, restaurants, etc.)

\begin{tabular}{|c|l|l|}
\hline Rights $\downarrow$ Rightsholders $\Longrightarrow$ & I & II \\
\hline Public Performance & SOCAN & Re:Sound \\
\hline Mechanical (Reproduction) & $\begin{array}{l}\text { CSI } \\
\text { (SODRAC, CMRRA) }\end{array}$ & $\begin{array}{l}\text { CONNECT, SOPROQ, } \\
\text { and Others }\end{array}$ \\
\hline
\end{tabular}

2. Internet radio (non-interactive or semi-interactive webcast like Pandora, Songza, Sirius XM)

\begin{tabular}{|c|l|l|}
\hline Rights $\downarrow$ Rightsholders $\Longrightarrow$ & II & I* \\
\hline Digital Performance & SOCAN & Re:Sound \\
\hline Mechanical (Reproduction) & $\begin{array}{l}\text { CSI } \\
\text { (SODRAC, CMRRA) }\end{array}$ & $--_{--*}$ \\
\hline
\end{tabular}

3. Music streaming services (interactive streaming services such as Spotify, Rdio, Apple Music, Google Play, Deezer, Tidal)

\begin{tabular}{|c|l|l|}
\hline Rights $₫ \quad$ Rightsholders $\Longrightarrow$ & I & II \\
\hline Digital Performance & SOCAN & Re:Sound \\
\hline Mechanical (Reproduction) & $\begin{array}{l}\text { CSI } \\
\text { (SODRAC, CMRRA) }\end{array}$ & --- \\
\hline
\end{tabular}

There are at this time no Collective involved in the determination and collection of performers' and sound recordings' (group II) mechanical (reproduction) royalty rates on Internet radio and music streaming services, as the labels negotiate directly with the users for the use and licensing of such rights if applicable.

4. Rate or Price setting/regulating Organization 
In Canada, the Copyright Board of Canada, established in 1989, is an economic regulatory body empowered to establish, either mandatorily or at the request of an interested party, the royalties to be paid for the use of copyrighted works, "when the administration of such copyright is entrusted to a collective society," The Board can act as an arbitrator if the collective society and a user cannot agree on the terms and conditions of a license.

As stated on its website, the Board certify tariffs in the following fields: the public performance or communication of musical works and, since the 1997 amendment to the Copyright Act, of sound recordings of musical works, the retransmission of distant television and radio signals, the reproduction of television and radio programs by educational institutions, and private copying.

The total amount of royalties generated by the tariffs the Board certifies is estimated at \$434 million in 2013: SOCAN collects \$220M, Retransmission \$109M, CSI \$33M, Re:Sound \$26M, Access Copyright \$18M (reproduction of literary works), Private Copying \$8M, Others \$20M.

\section{EUROPE (France, Germany, UK, Spain)}

This section provides a comparison between four European countries, namely France, the UnitedKingdom, Germany and Spain, regarding the current situation on the determination and collection of author's rights (group I) and neighboring rights (group II). ${ }^{51}$

\section{FRANCE}

\section{Author's Rights Organizations}

In terrestrial radio, live venues, and other public places, the organization responsible for the granting of licenses for public performance is SACEM (Société des Auteurs, Compositeurs et Editeurs de Musique). The collection and distribution of mechanical rights is made through the SDRM (Société pour l'administration du Droit de Reproduction Mécanique). SDRM includes the SACEM and the AEEDRM (Association des éditeurs pour l'exploitation des droits de reproduction mécanique). SDRM does not have its own repertoire of direct members. It has received the mandate to administer the repertoire of its founding member collectives.

\footnotetext{
${ }^{51}$ Among the sources consulted for this section:

http://ec.europa.eu/internal_market/copyright/docs/management/monitoring-report_en.pdf

http://ec.europa.eu/internal_market/copyright/docs/management/study-collectivemgmt_en.pdf https://societe.sacem.fr/docs/SACEM_statutes_2015.pdf https://circabc.europa.eu/sd/a/57a571ce-68d7-4014-9c0d-64955f39c8ed/sacem_fr.pdf http://www.scpp.fr/SCPP/Portals/0/DownLoads/Adhesion/REGLEMENT\%20GENERAL\%202011\%20.pdf http://www.spedidam.fr/medias/plaquette-spedidam-final-150306.pdf http://www.spedidam.fr/artistes/vos-droits/3_26_33 remuneration-equitable.html http://www.musikindustrie.de/lizenzen/ http://www.keanet.eu/docs/music\%20licensing\%20and\%20transaction\%20costs\%20-\%20full.pdf
} 
In Internet radio (non-interactive or semi-interactive webcasting), SACEM is responsible to administer the public performance rights and the mechanical (reproduction) rights. For music streaming services (interactive services), SACEM is responsible to administer the public performance rights and the mechanical (reproduction) rights. Public performance rights and mechanical rights are noticeably not separated, but treated together within the framework of a form of exploitation.

\section{Neighboring Rights Organizations}

In Terrestrial radio, live venues, and other events in public places, SPRE (Société pour la Perception de la Rémunération Equitable) is responsible for the collection and the distribution of neighboring rights. It is composed of four organizations: ADAMI (Société pour l'Administration des Droits des Artistes et Musiciens Interprètes), SPEDIDAM (Société de Perception et de Distribution des Droits des Artistes Interprètes de la Musique et de la danse), SCPP (Société Civile des Producteurs Phonographiques), and SPPF (Société des Producteurs de Phonogrammes en France). SACEM was mandated by SPRE to collect the equitable remuneration from events in public places on SPRE's account, but SPRE carries out the collection from radios directly.

According to Article 214-1 of the Intellectual Property Code, the fees collected by SPRE within the framework of neighboring rights (group II) are allocated for 50\% to the performing artists and 50\% to the record labels. Regarding the fees distributed to performing artists, $50 \%$ are attributed to SPEDIDAM and $50 \%$ are attributed to ADAMI.

In Internet radio (non-interactive or semi-interactive webcasting), SCPP administers the performance rights. SCPP also administers mechanical rights in this area ${ }^{52}$. In music streaming services (interactive streaming services), SCPP directly collects royalty payments on behalf of its members when their music is reproduced (mechanical rights), communicated and/or made available to the public. SPPF has signed an agreement with Deezer in $2007^{53}$. Nevertheless, it is still unknown whether SPPF is today mandated to administer the neighboring rights related to the use of music on streaming services. According to its statutes (Art. 3.1), SPPF's mandate is to administer the rights pertaining to communication and reproduction recognized by Art. L214-1 and L311-1 of the Intellectual Property Code, in which there is no reference to music streaming services.

As for the exploitation of music in the case of web radios, SPEDIDAM states that performing artists in France do not perceive any right when their music is made available to the public through music streaming services or on-demand downloads. Their rights are not taken into account by the

\footnotetext{
${ }^{52}$ For this organization at least, we can find a confirmation in the information they disclose on its website that they effectively administer the rights mentioned.

53 « Jérôme Roger, le directeur général de la SPPF. «L'accord avec la SACEM est une condition nécessaire mais pas suffisante » pour que Deezer soit 100\% légal, indique-t-il, ajoutant que la SPPF, qui peut négocier sur la musique en flux de type "webradio », n'est pas encore mandatée par ses membres pour engager des négociations concernant des offres de ce type. Elle se contente pour l'instant de "bien comprendre le modèle d'exploitation de Deezer » pour en expliquer le fonctionnement à ses membres, et le cas échéant, obtenir un mandat à partir du début de l'automne. »- Le Figaro (2007)
} 
Intellectual Property Code (Art. L 212-3) in the way this article is written, and as such, SPEDIDAM advocates for changes in the law.

\section{Rate or Price setting Organization}

SACEM is the price setting organization for author's rights. When setting its tariffs, in accordance with the European Court of Justice's and the French court's and competition authorities' case law, SACEM takes into account the economic value of both the use of music in a particular context and the service it provides. In certain areas, SACEM's tariffs are accepted by representatives of music users through negotiations, when SACEM enters into collective bargaining agreements with users' associations / organizations.

According to the article L214-4 of the Intellectual Property Code, the tariffs of the equitable remuneration (neighboring rights) are fixed by an Administrative Committee chaired by a representative from the State and composed in equal share of persons designated by the organizations representing music users on the one hand and of persons designated by the SPRE on the other hand. The decisions of the Committee are published in the "Journal Officiel de la République Française".

Although French case law does not prescribe specific methodology criteria as such, French courts may issue a ruling involving a CMO's tariffs (in particular in cases where users claim that tariffs are too high as an argument to justify their refusal to pay royalties for their use of music) which may have an impact on the concerned CMO's tariffs.

The supervisory body of the collective societies in France is the "Commission Permanente de Contrôle des SPRD", a committee affiliated to the "Cour des Comptes" (Court of Auditors), which supervises their accountancy and their management.

\section{GERMANY}

\section{Author's Rights Organizations}

In terrestrial radio, live venues, and other events in public places (clubs, restaurants, etc.), GEMA (Gesellschaft für Musikalische Aufführungs- und mechanische Vervielfältigung) is responsible for granting licenses for both public performance rights and mechanical rights.

In Internet radio (non-interactive or semi-interactive webcasting) and satellite radio, GEMA is responsible for administrating both digital performance rights and mechanical rights.

In music streaming services (interactive streaming services), GEMA is responsible for administrating both digital performance rights and mechanical rights.

2. Neighboring Rights Organizations 
In terrestrial radio, live venues, and other public places (clubs, restaurants, etc.), GVL (Gesellschaft zur Verwertung von Leistungsschutzrechten $\mathrm{mbH}$ ) is mandated to manage both performance rights and mechanical rights.

In Internet Radio (non-interactive or semi-interactive webcasting) and satellite radio, licenses for neighboring rights in the online sector generally have to be obtained directly from the rightsholders, not the GVL. Exceptions are the usage of background music on websites and webcasting for which GVL has published tariffs.

In music streaming services (interactive streaming services), there is no collective organization mandated to manage neighboring rights in the online sector.

\section{Rate or Price setting Organization}

The Collective Societies in Germany are required by law to set up the tariffs and to publish them as well as any changes in the Bundesanzeiger (Federal Official Publication). Thus, GEMA sets itself the tariffs applying to author's rights, acting as an effective monopoly. The tariffs established by GVL depend on the kind of music exploitation and are set as a percentage of the GEMA-tariff.

In terrestrial Radio, both GEMA's and GVL's basis of calculation is represented by the revenue of the licensee. Further the tariff in both cases equals a percentage thereof limited by a minimum amount. But the rates differ significantly. For the minimum amount the GEMA uses a very sophisticated method for determining the proportion of music, the music share and duration of the program to set an appropriate minimum amount. But GEMA has no insight in GVL's methodologies for setting up the percentage or minimum regarding their Radio tariff.

GEMA-field service licenses background music/ communication to the public. With regard to background music (not the actual broadcast) the majority of the tariffs are negotiated with the respective user-associations.

For public performances (discotheques, restaurants, hotels, etc.), the majority of the tariffs are negotiated with the respective user-associations. GVL mainly set an additional fee as a percentage of the GEMA remuneration.

The supervisory body of the collective societies is the German Patent and Trademark Office - DPMA, which ensure that collective societies comply with the law.

\section{UNITED-KINGDOM}

\section{Author's Rights Organizations}

In terrestrial radio, live venues, and other events in public places (clubs, restaurants, etc.), PRS for Music is responsible for granting licenses for both public performance rights and mechanical rights. 
PRS for Music is an operational alliance between the Mechanical Copyright Protection Society (MCPS) and The Performing Right Society (PRS).

In Internet radio (non-interactive or semi-interactive webcasting) and satellite radio, PRS for Music is responsible to administer both digital performance rights and mechanical rights for authors (group I).

In music streaming services (interactive streaming services), PRS for Music is responsible to administer both digital performance rights and mechanical rights.

\section{Neighboring Rights Organizations}

In terrestrial radio, live venues, and other events in public places (clubs, restaurants, etc.), PPL (Phonographic Performance Limited) is the organization which administers neighboring rights in the $\mathrm{UK}^{54}$. PRS for Music and PPL offer joint licensing arrangements for several kind of public places, such as schools, churches, small workplaces.

In Internet radio (non-interactive or semi-interactive webcasting) and satellite radio, PPL (Phonographic Performance Limited) is the organization which administers neighboring rights ${ }^{55}$.

In music streaming services (interactive streaming services), PPL (Phonographic Performance Limited) is the organization which administers neighboring rights ${ }^{56}$.

\section{Rate or Price setting Organization}

In the UK, the respective tariffs are set by the collecting societies, often following negotiation with a trade body for the relevant affected industry sector and/or key interested parties. A scheme may be referred to the Copyright Tribunal, which has certain powers to confirm or vary a scheme. During the course of negotiations with the relevant trade body, the threat of a tribunal reference may be made which in itself may have an impact on the tariff set as a result of that negotiation.

\section{SPAIN}

\section{Author's Rights Organizations}

In terrestrial radio, live venues, and other events in public places (clubs, restaurants, etc.), SGAE (Sociedad General de Autores y Editores - Collecting Society for Authors and Publishers) is the

\footnotetext{
54 At least with regard to public performance. PPL does not mention the administration of mechanical rights on its website.

${ }^{55}$ At least with regard to digital performance.

${ }^{56}$ At least with regard to digital performance.
} 
author's rights organization in Spain. It is mandated to manage both performance and mechanical rights.

In Internet radio (non-interactive or semi-interactive webcasting) and satellite radio, SGAE is competent to administer digital performance rights and mechanical rights for authors (group I).

In Music streaming services (interactive streaming services), SGAE is competent to administer author's rights with regard to digital performance in the field of music streaming services. SGAE's tariffs are $10 \%$ of the user's total income with respect to the streaming exploitations, and $12 \%$ of the user's total income with respect to downloading exploitations (2013).

2. Neighboring Rights organizations

In terrestrial radio, live venues, and other events in public places (clubs, restaurants, etc.), the management of neighboring rights is shared between two organizations, namely AIE (Artistas Intérpretes y Ejecutantes), which administers the rights of performing artists, and AGEDI (Asociacion de Gestion de Derechos Intelectuales), representing music producers. AIE and AGEDI work together with respect to the collection activity, through an organization called OCR (Organo Conjunto de Recaudacion).

In Music streaming services (interactive streaming services) is competent to administer neighboring rights within the framework of music streaming services.

\section{Rate or Price setting Organization}

Rates and tariffs are set by the collecting societies in their respective area, i.e. SGAE for author's rights and AIE-AGEDI for neighboring rights. For the latter, tariffs are fixed by common agreements between AIE and AGEDI. There have been several cases in which users appealed to the Spanish Competition Authority to question the tariffs imposed by the collecting societies representing artists and producers. In many decisions rendered by the courts and authorities, these collecting societies were recognized as abusing a monopolistic position.

\section{EU-wide licensing}

Some EU-wide licensing initiatives are listed below:

- SACEM, SGAE, and the Italian SIAE launched ARMONIA (2007), a Joint-Venture whose mandate is to license the online and mobile uses of the repertoire of the three societies and manage their online rights.

- CELAS (Central European Licensing and Administration Services) has been set up by GEMA and MCPS-PRS to cover the EMI Music Publishing's Anglo-American and German repertoire for online and mobile uses. 
- In an initiative called PEDL, (Pan-European Digital Licensing), GEMA, MCPS-PRS, and the Swedish STIM signed agreements with Warner/Chappell Music to provide EU-wide digital licenses covering Warner/Chappell's Anglo-American repertoire.

- SACEM-UMPG Initiative: SACEM and Universal Music Publishing Group signed an agreement covering online and mobile uses of their joint repertoire. 